\title{
Synthesis, screening and docking of small heterocycles as Glycogen Phosphorylase inhibitors
}

Stephanie S. Schweiker, ${ }^{\mathrm{a}, \mathrm{b}}$ Wendy A. Loughlin,,${ }^{\mathrm{a}, \mathrm{c},}{ }^{*}$ Anna S. Lohning, ${ }^{\mathrm{c}}$ Maria J. Petersson, ${ }^{\mathrm{a}}$ Ian D. Jenkins, ${ }^{a}$

${ }^{a}$ Eskitis Institute for Drug Discovery, Nathan Campus, Griffith University, Brisbane, QLD, 4111, Australia

${ }^{b}$ Faculty of Health Sciences and Medicine, Bond University, Gold Coast, QLD, 4229, Australia

${ }^{c}$ School of Biomolecular and Physical Sciences, Nathan Campus, Griffith University, Brisbane, QLD, 4111, Australia

Corresponding author. Tel.: +61 (0)7 37357567

E-mail address: w.loughlin@griffith.edu.au

\begin{abstract}
A series of morpholine substituted amino acids (phenylalanine, leucine, lysine and glutamic acid) was synthesized. A fragment-based screening approach was then used to evaluate a series of small heterocycles, including morpholine, oxazoline, dihydro-1,3-oxazine, tetrahydro-1,3-oxazepine, thiazoline, tetrahydro-1,3-pyrimidine, tetrahydro-1,3-diazepine and hexahydro-1H-benzimidazole, as potential inhibitors of Glycogen Phosphorylase a. Thiazoline 7 displayed an improved potency $\left(\mathrm{IC}_{50}\right.$ of $\left.25 \mu \mathrm{M}\right)$ and had good LE and LELP values, as compared to heterocycles $\mathbf{1}, \mathbf{5 , 9 - 1 3}$ and 19 ( $\mathrm{IC}_{50}$ values of $1.1 \mathrm{mM}$ to $\left.23.9 \mathrm{mM}\right)$. A docking study using the crystal structure of human liver Glycogen Phosphorylase, provided insight into the interactions of heterocycles 5, 7, 9-13 and 19 with Glycogen Phosphorylase.
\end{abstract}

\section{Keywords}

Glycogen Phosphorylase a

Fragment screening

Molecular docking

Thiazoline 
Tetrahydropyrimidine

Heterocycle

\section{Introduction}

Glycogen Phosphorylase (GP) is a molecular therapeutic target for treating hyperglycaemia associated with Type II Diabetes Mellitus [1-5]. GP plays a crucial role in carbohydrate metabolism, catalysing the phosphorolysis of glycogen to form glucose-1-phosphate which can be utilised to form ATP in muscle cells or in the case of hepatocytes, to form glucose for maintaining blood glucose levels. This is reflected in the distribution of three main isoforms of GP in the body; muscle, liver, brain. Glycogen phosphorylase is a tightly regulated allosteric enzyme with several binding sites [6] for allosteric effectors (purine site [7], indole site [8,9], allosteric (AMP) site [1,10], new allosteric site [11]) in addition to the catalytic $[12,13]$ and storage sites [14]. Comprehensive reviews on a range of GP inhibitors have been reported in the patent literature $[15,16]$ and elsewhere $[1,2,17-24]$.

Allosteric manipulation of GP allows for the exploration of structurally unique molecules as agents for regulatory control of GP. Notably, the majority of allosteric inhibitors inhibit GP at the new allosteric (indole) or allosteric (AMP) site and are typically N-heterocycles. Compared to glucose analogues (which typically show an $\mathrm{IC}_{50}=$ half maximal inhibitory concentration in the $\mathrm{mM}$ to $\mu \mathrm{M}$ range of inhibition) the indole drugs are more potent with $\mathrm{nM}$ range inhibition [20]. Heterocyclic compounds that have been identified as GP inhibitors include: caffeine [7], flavopiridol [25] and purine derivatives [6](purine nucleoside site, also known as the 'inhibitor' site); indirubin [26] and phthalic acid derivatives [6](AMP site); pyridine derivatives [6] (Bay W1807) (AMP site); indole-carboxamide derivatives, 3,4dihydroquinolin-2-ones and 5-chloroindoles (another allosteric site at the enzyme dimer interface) [26-29]. Recent examples, which continue to demonstrate the importance of exploration of structural diversity using heterocylic moieties, include conjugates of Dglucose, 1,3,4-oxadiazole, and 1,2,3-triazole [30], 1-xylosyl-4-substituted 1,2,3-triazoles [31], C-Glucopyranosyl-1,2,4-triazoles [32], C5-alkynyl, 4,5-spirolactams [33], alkylfurano[2,3d]pyrimidine glucopyranonucleosides [34], and heterocyclic N-( $\beta$-Dglucopyranosyl)carboxamides [35].

Lead-like discovery refers to the screening of low molecular weight libraries with detection of weak affinities in the high micromolar to millimolar range [36]. These low molecular 
weight libraries are often referred to as fragment libraries. Fragment screening using high concentration biochemical assays provides another approach to methods such as NMR spectroscopy or high-throughput X-ray crystallography $[37,38]$. The heterocycle library reported herein (Fig. 1) was chosen to broaden the consideration of simple heterocycles currently reported and was based on selected variations of ring size, heteroatom substitution and synthetic accessibility.

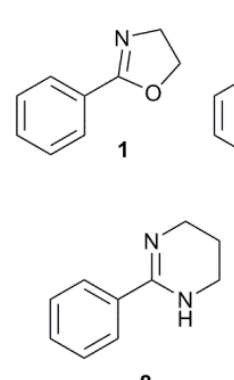<smiles>O=C(NC(Cc1ccccc1)C(=O)N1CCOCC1)OCc1ccccc1</smiles><smiles>CC(C)CC(NC(=O)OCc1ccccc1)C(=O)N1CCOCC1</smiles>
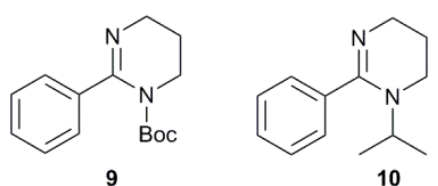<smiles>NC(Cc1ccccc1)C(=O)N1CCOCC1</smiles>

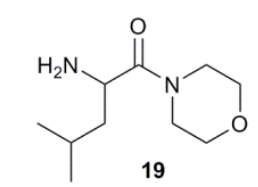

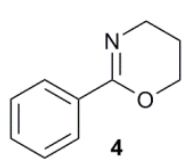

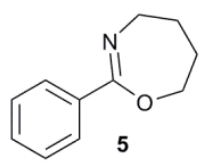<smiles>c1ccc(C2=NCCS2)cc1</smiles><smiles>CC(=O)C1CSC(c2ccccc2)=N1</smiles><smiles>CC1(C)CN=C(c2ccccc2)NC1</smiles><smiles>c1ccc(C2=NCCCCN2)cc1</smiles>

12<smiles>c1ccc(C2=NC3CCCCC3N2)cc1</smiles><smiles>CNCCCCC(NC)C(=O)N1CCOCC1</smiles><smiles>O=C(O)CCC(NC(=O)O)C(=O)N1CCOCC1</smiles><smiles>NCCCCC(N)C(=O)N1CCOCC1</smiles><smiles>NC(CCC(=O)O)C(=O)N1CCOCC1</smiles>

Fig. 1. Structures of heterocyclic compounds 1-21 in fragment library.

In combination and synergy with this approach, we built on our previous work where the key residues of EKL within the peptide chain of PEWPSYLGYEKLGPYY $-\mathrm{NH}_{2}$ were identified as having additional molecular interactions with GPa [39]. Based on atom placement, bond torsion angles and synthetic accessibility, the morpholine scaffold provided a potential scaffold for mimetics of EKL, as shown in Figure 2. Due to synthetic accessibility, the focus of the present set of analogs was mono-functionalization of the morpholine scaffold (where $\mathrm{R}$ $=\mathrm{H}$ ) with amino acids (Lys and Glu (polar); Leu (aliphatic); Phe (aromatic)) and was cognisant of EKL. These simpler analogs may be not of optimal biological potency but were anticipated to establish the proof-of concept. 


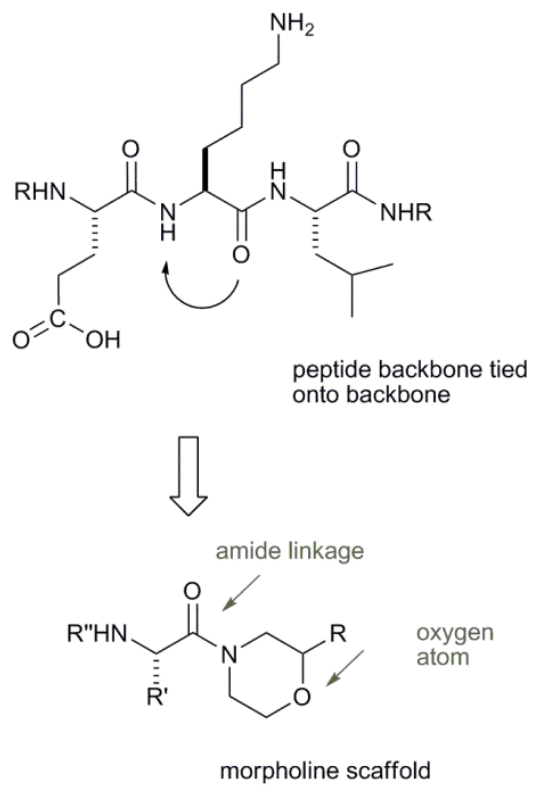

Fig. 2. Morpholine scaffold mimetic of peptide backbone

Herein we explore the identification of new heterocyclic inhibitors of GP using a fragment screening approach, and explore the molecular interactions of small heterocycles with inhibitory activity against human liver Glycogen Phosphorylase (HLGP) using a structurebased computational approach to disclose new heterocyclic structures targeting GP.

\section{Chemistry}

The synthesis of oxazolines $\mathbf{1 - 3}$, dihydro-1,3-oxazine $\mathbf{4}$, tetrahydro-1,3-oxazepine $\mathbf{5}$, thiazolines 6-7, tetrahydro-1,3-pyrimidines 8-11, tetrahydro-1,3-diazepine 12, hexahydro-1Hbenzimidazole 13, is reported elsewhere [40,41]. N-Cbz protection of commercially available phenylalanine 22, N-Cbz Lysine 24, and leucine 26 with benzoylchloroformate and sodium hydroxide was followed by coupling of morpholine to the Cbz-amino acids 23, 25 and 27 respectively, under standard conditions (HOBt, EDC.Cl, DIPEA) [42]. Hydrogenation of Cbz-protected morpholines 14, 16 and 18 gave amino acid morpholines 15, 17, and 19 respectively.

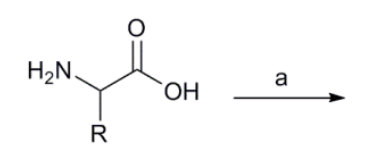

$22 \mathrm{R}=\mathrm{Bn}$

$24 \mathrm{R}=(\mathrm{CH})_{4} \mathrm{NHCbz}$ $26 \mathrm{R}=\mathrm{CH}\left(\mathrm{CH}_{3}\right)_{2}$<smiles>[R]C(NC(=O)OCc1ccccc1)C(=O)O</smiles>

$23 \mathrm{R}=\mathrm{Bn}$

$25 \mathrm{R}=(\mathrm{CH})_{4} \mathrm{NHCbz}$ $27 \mathrm{R}=\mathrm{CH}\left(\mathrm{CH}_{3}\right)_{2}$<smiles>[R]C(NC(=O)N1CCOCC1)C(=O)N1CCOCC1</smiles>

$\begin{aligned} 14 \mathrm{R} & =\mathrm{Bn} \\ 16 \mathrm{R} & =(\mathrm{CH})_{4} \mathrm{NHCbz}\end{aligned}$ $18 \mathrm{R}=\mathrm{CH}\left(\mathrm{CH}_{3}\right)_{2}$
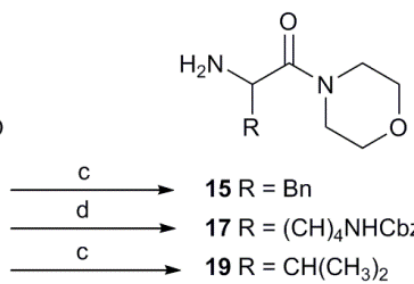

$15 \mathrm{R}=\mathrm{Bn}$

$17 \mathrm{R}=(\mathrm{CH})_{4} \mathrm{NHCbz}$ $19 \mathrm{R}=\mathrm{CH}\left(\mathrm{CH}_{3}\right)_{2}$ 
Scheme 1: Synthesis of morpholines 15, 17 and 19 (a) $\mathrm{NaOH}$, benzyl chloroformate, rt, 30 min; (b) morpholine, EDC.HCl, HOBt, DIPEA, rt, 16 h; (c) $\mathrm{H}_{2}$, Pd-C, ethanol, acetic acid, rt 48 h; (d) $\mathrm{H}_{2}$, Pd-C, ethyl acetate, rt, 48 h.

However, when Glu(OBzl)-OH was reacted with benzyl chloroformate and $\mathrm{NaOH}$ in the above sequence (Scheme 1), de-protected glutamic acid was obtained, as confirmed by mass spectrometry. Instead Boc-Glu(OBn)-OH 28 was coupled with morpholine under standard conditions (HOBt, EDC.Cl, DIPEA) [42], and Boc-Glu(OBn)-morpholine 29 was obtained. Sequential deprotection of $\mathbf{2 9}$ by hydrogenation, and Boc group cleavage from Boc-Glumorpholine 20 using $\mathrm{HCl}$ /ether gave $\mathrm{H}_{2} \mathrm{~N}$-Glu-morpholine 21. Compounds 14-21, 23, 25, 27, 29 were purified by silica chromatography and characterization of the final compounds 14-21 was confirmed by ${ }^{1} \mathrm{H}$ and ${ }^{13} \mathrm{C}$ NMR spectroscopy.

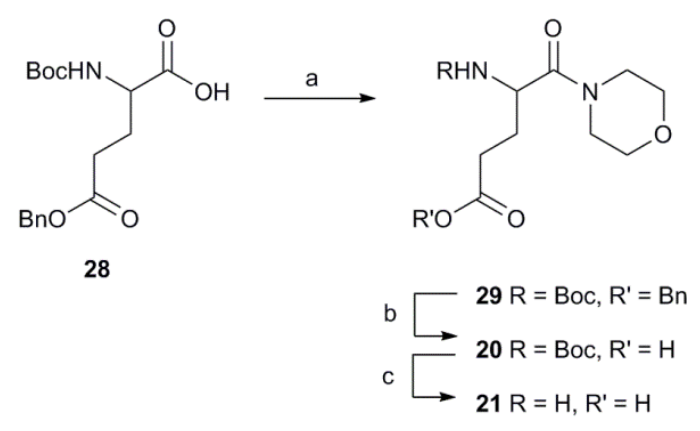

Scheme 2: Synthesis of morpholine 21 (a) morpholine, EDC.HCl, HOBt, DIPEA, rt 16 h; (b) $\mathrm{H}_{2}$, Pd-C, ethyl acetate, rt 48 h; (c) HCl/Ether, rt 2 h.

\section{Molecular Properties and drug-likeness}

The molecular properties such as molecular size, solubility, lipophilicity, flexibility, and presence of hydrogen bonding sites influence the 'drug-like' characteristics of a compound. In order to assist the evaluation of the small heterocycles we subjected compounds 1-21 to prediction of solubility, lipophilicity, Lipinski 'Rule of Five' [43] and the fragment definition; a compound that obeys the 'Rule of Three,' [44] where MW $<300$ Da, cLogP $<3$, H-bond donors $(\mathrm{OH}, \mathrm{NH})<3$, H-bond acceptors $(\mathrm{O}, \mathrm{N})<3$, number of rotatable bonds $\left(\right.$ ROTB) $<3$, and topological polar surface area (TPSA) $<60 \AA^{2}$. Numerical values for lipophilicity $(\log \mathrm{P})$, solubility $\log \mathrm{S}(\mathrm{mol} / \mathrm{L})$, topological polar surface area (TPSA), 
number of $\mathrm{H}$-bond donors (\#OHNH), number of oxygen and nitrogen atoms (\#ON), and number of rotatable bonds (\#RB) (Table 1) were calculated with ALOGPS $2.1[45,46]$.

In Table 1, compounds $\mathbf{1 - 2 1}$ have a predicted $\log \mathrm{P}<5$ in accordance with Lipinski's rules $[43,47]$, and another study which suggests a value of $<3.5$ for $\log P$ is preferred for lead-like compounds [48]. In addition, a low $\log P$ in the range of $0-3$ is desirable to reduce toxicity and increase ease of formulation and bioavailability for optimal oral absorption. All compounds studied had $\log \mathrm{P}$ values within the desired range for optimal oral absorption, apart from compounds 9 and 19, which had values 0.1 outside the desired range, and inactive compounds 17 and 21 with $\log \mathrm{P}$ values $<0$.

An indication of the solubility of a compound (S) can be given by the LogS value. As reviewed elsewhere [49] an acceptable level of solubility is critical to permit dissolution and absorption. Absorption of a drug is usually very low if the calculated solubility is $<0.00001 \mathrm{mg} / \mathrm{L}$, as shown in a study of the rate-limiting steps of human oral absorption of 238 drugs [50]. The $\log S$ values were calculated using ALOGPS 2.1 and the compounds could be classified into; those with lower calculated solubility from the interval between $20-70 \mathrm{mg} / \mathrm{L}$ (compound 16), those with calculated solubility from the interval between 0.1 and $3.5 \mathrm{~g} / \mathrm{L}$ sufficient for fast adsorption, (compounds 1-14 and 18) and those that had higher calculated solubility, above $7 \mathrm{~g} / \mathrm{L}$ (compound 15, 17, 19-21). Compound solubility is also a consideration when doing fragment screening in vitro where high concentrations $\leq \mathrm{mM}$ are required. Compounds 1-21 were all soluble at a maximal concentration of $22-222 \mathrm{mM}$ for the GP assay (section 3).

Topological polar surface area (TPSA) (the solvent accessible area of the compound which will interact with the solvent in a dipole or hydrogen bond (H-bond) interaction) [47] is, together with lipophilicity and solubility, widely acknowledged as an important factor in transport across membranes. It has been suggested that compounds which are to be passively absorbed should have a maximum TPSA of $120 \AA^{2}$ [51]. In Table 1, compounds 1-21 were all predicted to have a TPSA under this limit.

Hydrogen-bonding capacity has been identified as an important parameter for describing drug permeability [52,53]. An excessive number of H-bond donors $(>5)$ and/or a high number of oxygen and nitrogen atoms $(\geq 10)$ can result in poor absorption. In Table 1 , for compounds 1- 
21 the number of H-bond acceptors per compound is < $10(1-9)$ and the number of H-bond donors is $\leq 4$, and within the suggested limits.

Reduced molecular flexibility measured by the number of rotatable bonds (optimally below eight) is another important predictor of good oral bioavailability [52,53]. In Table 1, compounds 1-13, 15, 19, and 21 all have a low number of rotatable bonds $<5$ as they all possess a high to moderate degree of structural rigidity or have less functionality. Whereas, compounds 14, 16-18, and 20 have a higher number of rotatable bonds $>5$ ( $7-13)$, due to the substituted peptidic structures of these compounds.

Compound libraries used in fragment screening should obey the 'Rule of Three', which is preferred for identifying hits for further development and optimization. The compounds in Table 1, 1, 2, 4-8, 10-13 abide by the 'rule of 3'. Compounds 14-21 do not abide by the 'rule of 3' as they have a peptidic structure which results in ROTB > 3, and H-bond donors > 3 . 
Table 1

Calculated Lipinski Parameters and GPa inhibition results for compounds 1-21.

\begin{tabular}{|c|c|c|c|c|c|c|c|c|c|c|}
\hline Cpd & MW & $\begin{array}{l}\text { GPa \% } \\
\text { inhibition }^{\text {a }} \\
\text { or estIC }_{50} \\
(\mathrm{mM})^{\mathrm{c}}\end{array}$ & $\log \mathrm{P}^{\mathrm{b}}$ & $\begin{array}{l}\log S^{b} \\
(\mathrm{~mol} / \mathrm{L})\end{array}$ & $\begin{array}{c}\# \\
\text { ROTB }\end{array}$ & $\begin{array}{l}\# \\
\mathrm{ON}\end{array}$ & $\begin{array}{l}\# \\
\mathrm{OH} \\
\mathrm{NH}\end{array}$ & TPSA & \begin{tabular}{l}
\multicolumn{1}{c}{$\#$} \\
Lipinski \\
violations
\end{tabular} & $\begin{array}{l}\# \\
\text { rule of } 3 \\
\text { violations }\end{array}$ \\
\hline 1 & 147 & 23.9 & $1.81 \pm 0.39$ & $-2.02 \pm 0.16$ & 2 & 1 & 0 & 21.598 & 0 & 0 \\
\hline 2 & 161 & $78 \%$ at 111 & $2.20 \pm 0.41$ & $-2.35 \pm 0.19$ & 1 & 2 & 0 & 21.598 & 0 & 0 \\
\hline 3 & 192 & $94 \%$ at 56 & $1.69 \pm 0.38$ & $-2.59 \pm 0.16$ & 2 & 5 & 0 & 67.422 & 0 & 2 \\
\hline 4 & 161 & $39 \%$ at 111 & $2.13 \pm 0.48$ & $-2.31 \pm 0.26$ & 1 & 2 & 0 & 21.598 & 0 & 0 \\
\hline 5 & 175 & 1.4 & $2.54 \pm 0.49$ & $-2.61 \pm 0.38$ & 1 & 2 & 0 & 21.598 & 0 & 0 \\
\hline 6 & 163 & $39 \%$ at 22 & $2.44 \pm 0.56$ & $-2.64 \pm 0.53$ & 1 & 1 & 0 & 12.364 & 0 & 0 \\
\hline 7 & 221 & 0.025 & $2.07 \pm 0.53$ & $-2.75 \pm 0.46$ & 3 & 3 & 0 & 38.669 & 0 & 0 \\
\hline 8 & 160 & $99 \%$ at 222 & $1.76 \pm 0.61$ & $-1.95 \pm 0.41$ & 1 & 2 & 1 & 24.391 & 0 & 0 \\
\hline 9 & 260 & 1.1 & $3.09 \pm 0.77$ & $-3.18 \pm 0.16$ & 3 & 4 & 0 & 41.907 & 0 & 1 \\
\hline 10 & 202 & 7.2 & $2.82 \pm 0.63$ & $-2.42 \pm 0.32$ & 2 & 2 & 0 & 15.602 & 0 & 0 \\
\hline 11 & 188 & 1.2 & $2.52 \pm 0.62$ & $-2.60 \pm 0.37$ & 1 & 2 & 1 & 24.391 & 0 & 0 \\
\hline 12 & 174 & 3.0 & $2.16 \pm 0.65$ & $-2.33 \pm 0.35$ & 1 & 2 & 1 & 24.391 & 0 & 0 \\
\hline 13 & 200 & 7.8 & $2.74 \pm 0.58$ & $-3.19 \pm 0.08$ & 1 & 2 & 1 & 24.391 & 0 & 0 \\
\hline 14 & 368 & $\mathrm{n} / \mathrm{a}$ & $2.61 \pm 0.79$ & $-3.33 \pm 0.47$ & 7 & 6 & 1 & 67.875 & 0 & 4 \\
\hline 15 & 234 & $20 \%$ at 222 & $0.23 \pm 0.43$ & $-1.29 \pm 0.04$ & 3 & 4 & 2 & 55.566 & 0 & 1 \\
\hline 16 & 483 & $5 \%$ at 222 & $3.11 \pm 1.10$ & $-4.05 \pm 0.59$ & 13 & 9 & 2 & 106.207 & 0 & 5 \\
\hline 17 & 215 & $\mathrm{n} / \mathrm{a}$ & $-1.31 \pm 0.46$ & $-0.33 \pm 0.27$ & 5 & 5 & 4 & 81.589 & 0 & 3 \\
\hline 18 & 334 & $\mathrm{n} / \mathrm{a}$ & $2.37 \pm 0.92$ & $-2.83 \pm 0.17$ & 7 & 6 & 1 & 67.875 & 0 & 4 \\
\hline 19 & 200 & 6.5 & $-0.01 \pm 0.42$ & $-0.64 \pm 0.15$ & 3 & 4 & 2 & 55.566 & 0 & 2 \\
\hline 20 & 316 & $12 \%$ at 111 & $0.26 \pm 0.66$ & $-1.21 \pm 0.49$ & 7 & 8 & 2 & 105.174 & 0 & 4 \\
\hline 21 & 216 & $25 \%$ at 222 & $-2.25 \pm 0.90$ & $-0.17 \pm 0.12$ & 4 & 6 & 3 & 92.865 & 0 & 3 \\
\hline
\end{tabular}

a average values from 4 determinations (duplicates on two separate occasions) with a Hill slope between 0.5 and 3.0 and $Z$ ' values of $\sim 0.8$.

${ }^{\mathrm{b}}$ determined from ALOGPS 2.1

${ }^{c}$ estimated $\mathrm{IC}_{50}$ reported with \% GPa inhibition observed at maximal concentration $(22 \mathrm{mM}$, $56 \mathrm{mM}, 111 \mathrm{mM}$ or $222 \mathrm{mM})$. 


\section{Glycogen Phosphorylase a Screening}

\subsection{Glycogen Phosphorylase a Activity}

The activity of GP in the presence of compounds 1-21 was measured using the in vitro GP screen reported in other studies [54], in the direction of glycogen synthesis by the formation of inorganic phosphate from glucose-1-phosphate [55,56]. The maximal concentration of compound used in the assay was $222 \mathrm{mM}$. Caffeine was used as the standard and gave an $\mathrm{IC}_{50}=283 \pm 10 \mu \mathrm{M}$ under the assay conditions. Compounds 2-4, 6, 8, 14-18, and 20-21 showed little to no inhibition, whereas compounds 1, 5, 9-13 and 19 displayed millimolar inhibition of GP (Table 1). By comparison thiazoline 7 displayed an improved potency with an $\mathrm{IC}_{50}$ of $25 \mu \mathrm{M}$ (Table 1). It was interested to note that by comparison compound 6 displayed reduced potency ( $\mathrm{GPa}$ inhibition of $39 \%$ at $22 \mathrm{mM}$ ), implying that the ester functionality in compound 7 was a key

\subsection{Ligand Efficiency and Ligand-Efficiency-dependent Lipophilicity}

The compounds with defined activity against GPa were analysed for ligand efficiency (LE) and Ligand-Efficiency-dependent Lipophilicity (LELP) to provide further assessment of the quality of the hits obtained from the GPa screening. The calculated values for LE and LELP for compounds $\mathbf{1 , ~ 5 , ~ 7 , ~ 9 - 1 3 ~ a n d ~} 19$ are shown in Table 2. Considering the acceptable lower limit of LE (0.3) and the optimal range of LELP (-10 < LELP < 10) [57] this narrowed consideration of the promising hits to compound 7, with compounds $\mathbf{5}$ and $\mathbf{1 1}$ being second tier hits. 
Table 2

Calculated Ligand Efficiency (LE) and Ligand-Efficiency-dependent Lipophilicity (LELP) of compounds $\mathbf{1 , 5}, \mathbf{7 , 9 - 1 3}$ and 19

\begin{tabular}{llllr}
\hline Compound & $\begin{array}{c}\text { GPa inhbition }^{\mathrm{a}} \\
\text { estIC }_{50}(\mathrm{mM})^{\mathrm{c}}\end{array}$ & LE & $\mathrm{cLogP}^{\mathrm{b}}$ & LELP \\
\hline $\mathbf{1}$ & 23.9 & 0.20 & $1.81 \pm 0.39$ & 9.05 \\
$\mathbf{5}$ & 1.4 & 0.30 & $2.54 \pm 0.49$ & 8.47 \\
$\mathbf{7}$ & 0.025 & 0.42 & $2.07 \pm 0.53$ & 4.93 \\
$\mathbf{9}$ & 1.1 & 0.21 & $3.09 \pm 0.77$ & 14.71 \\
$\mathbf{1 0}$ & 7.2 & 0.20 & $2.82 \pm 0.63$ & 14.10 \\
$\mathbf{1 1}$ & 1.2 & 0.29 & $2.52 \pm 0.62$ & 8.69 \\
$\mathbf{1 2}$ & 3.0 & 0.27 & $2.16 \pm 0.65$ & 8.31 \\
$\mathbf{1 3}$ & 7.8 & 0.19 & $2.74 \pm 0.58$ & 14.42 \\
$\mathbf{1 9}$ & 6.5 & 0.21 & $-0.01 \pm 0.42$ & -0.05 \\
& & & & \\
\hline
\end{tabular}

\footnotetext{
${ }^{a}$ average values from 4 determinations (duplicates on two separate occasions) with a Hill slope between 0.5 and 3.0 and Z' values of $\sim 0.8$.

\section{Molecular Modelling and Molecular Docking}

\subsection{Validation of model}

Validation for the docking method involved determining the heavy atom root mean square deviation (RMSD) between the original X-ray structure ligand conformation and its docked pose. The ligands were removed from their X-ray structure and minimised prior to being docked into their appropriate site using Surflex-Dock. Validation of the site involved docking ligand 30, 31 and 32 in the purine and indole sites [7] (PDB ID: 1L5Q) and AMP site [58] (PDB ID: 3DDS) respectively. The RMSD between each ligand and its docked pose was found; $0.5 \AA$ (AMP), $0.1 \AA$ (purine) and $2.0 \AA$ (indole). An RMSD of less than $2 \AA$ is generally considered a good reproduction of the crystal structure conformation. Subsequent docking of ligands was thereafter assumed to be reasonably well predicted by Surflex-Dock. In this experiment Cscore (Consensus score) was included as it provides a more robust scoring function as it combines a number of scoring algorithms to produce a consensus superior to 
that of any single function for evaluating ligand-receptor interactions. The number of rotatable bonds considered in each docking run greatly increases accuracy as well as run time. Including protein and ligand flexibility partially addresses previous docking limitations however the number of degrees of freedom required to adequately address protein flexibility still remains beyond current technology. Predicting receptor structural rearrangements is a very complex problem which has not been solved. Note that the Surflex-Dock docking model does not predict bridging water molecules in the binding site unless crystal waters are defined as part of the target structure. In this case no water molecules were included to be consistent for the docking across the three different binding sites.

\subsection{Analysis}

Compounds 5, 7, 9, 11-13 and 19 were docked into each of the AMP, purine and indole binding sites of HLGP. The total Cscores for each docking run, expressed as $-\log K_{d}$, were within site confidence and are shown in Table 2.

Table 3

Cscore values for compounds 5, 7, 9, 11-13 and 19 docked into AMP, purine and indole binding sites of HLGP

\begin{tabular}{lllll}
\hline Compound & $\begin{array}{l}\mathrm{GPa}_{\text {\% inhibition }}^{\mathrm{a}} \\
\text { or estIC }_{50}(\mathrm{mM})^{\mathrm{c}}\end{array}$ & $\begin{array}{l}\text { AMP site score }^{\mathrm{b}} \\
\text { RMSD 0.6 }\end{array}$ & $\begin{array}{l}\text { Purine site score }^{\mathrm{b}} \\
\text { RMSD 1.0 }\end{array}$ & $\begin{array}{l}\text { Indole site score }^{\mathrm{b}} \\
\text { RMSD 2.0 }\end{array}$ \\
\hline $\mathbf{5}$ & 1.4 & 4.6 & 5.8 & 4.1 \\
$\mathbf{7}$ & 0.025 & 5.2 & 5.3 & 4.3 \\
$\mathbf{9}$ & 1.1 & 5.3 & 6.7 & 5.0 \\
$\mathbf{1 0}$ & 7.2 & 4.9 & 5.6 & 4.0 \\
$\mathbf{1 1}$ & 1.2 & 4.3 & 5.8 & 4.7 \\
$\mathbf{1 2}$ & 3.0 & 4.5 & 5.4 & 4.8 \\
$\mathbf{1 3}$ & 7.8 & 4.1 & 5.0 & 4.9 \\
$\mathbf{1 9}$ & 6.5 & 6.2 & 6.4 & 5.3 \\
$\mathbf{3 0}$ & $0.648^{\mathrm{d}}$ & $\mathrm{n} / \mathrm{a}$ & 5.4 & $\mathrm{n} / \mathrm{a}$ \\
$\mathbf{3 1}$ & $0.045 \times 10^{-3 \mathrm{~d}}$ & $\mathrm{n} / \mathrm{a}$ & $\mathrm{n} / \mathrm{a}$ & 9.5 \\
$\mathbf{3 2}$ & $0.007 \times 10^{-3 \mathrm{~d}}$ & 15.3 & $\mathrm{n} / \mathrm{a}$ & $\mathrm{n} / \mathrm{a}$ \\
\hline
\end{tabular}

${ }^{a}$ average values from 4 determinations (duplicates on two separate occasions) with a Hill slope between 0.5 and 3.0 and $Z$ ' values of $\sim 0.8$.

${ }^{\mathrm{b}}$ total Cscore for each docking run, expressed as $-\log \mathrm{K}_{\mathrm{d}}$

${ }^{c}$ estimated $\mathrm{IC}_{50}$ reported with \% GPa inhibition observed at maximal concentration.

${ }^{\mathrm{d}} \mathrm{IC}_{50}$ reported in PDB. 


\section{Results and discussion}

Illustrative examples of small heterocyclic compounds typically not reported against GP, such as oxazolines 1-3 [41], dihydro-1,3-oxazine 4 [41], tetrahydro-1,3-oxazepine 5 [41], thiazolines 6-7 [41], tetrahydropyrimidines 8-11 [40], tetrahydrodiazepine 12 [40], hexahydro-1H-benzimidazole 13 [40], and morpholines (scaffold for mimetics of EKL) 1421 were synthesized. Compounds 1-21 formed a 'fragment' library and were evaluated against molecular property criteria that influence the 'drug-like' characteristics of a compound; molecular size, solubility, lipophilicity, flexibility, and presence of hydrogen bonding sites. Furthermore, compounds 1-21 were evaluated for their ability to inhibit commercially available rabbit muscle Glycogen Phosphorylase a. The combined results provided a subset of compounds $\mathbf{5}, \mathbf{7 ,}, \mathbf{9 - 1 3}$ and $\mathbf{1 9}$, which had an $\mathrm{IC}_{50}<7.8 \mathrm{mM}$ (comparable to literature compounds), and met either the rule of five (9 and 19) or rule of three $(\mathbf{5 , 7 , 1 0 -}$ 13) in combination with reasonable values for predicted $\log \mathrm{P}$ and $\log S$. Within the subset of 5, 7, 9-13 and 19, correlations between the structure of an individual compound and bioactivity were not obvious. It was interesting to note that a direct comparison of the potency of compound 7 (IC50 $=25 \mathrm{uM})$ to the potency of the other compounds, in particular the reduced potency of compound 6 ( $\mathrm{GPa}$ inhibition of $39 \%$ at $22 \mathrm{mM}$ ) suggested that the ester functionality in compound 7 was influential on bioactivity. This could be explored in detail in the future through further SAR and binding studies. In the present fragment library, further analysis of the subset of 5, 7, 9-13 and 19, using LE and LELP indicated that compound 7 was a promising hit, with compounds 5 and $\mathbf{1 1}$ being second tier hits. To potentially facilitate a level of understanding, the molecular interactions of 5, 7, 9-13 and 19 with human liver glycogen phosphorylase was explored in silico, whilst acknowledging that weak binding to GP binding sites is likely to be observed by the virtue of the low MW of compounds 5, 7, 9-13 and 19.

Validation of the site was carried out by docking ligands 30, $\mathbf{3 1}$ and 32, which are selective for each site, into the purine and indole sites [7] (PDB ID: 1L5Q) and AMP site [58] (PDB ID: 3DDS) respectively, of human liver GP from the RCSB Protein Data Bank. Human liver GP was selected for study since this isoform presents the most important target for GP inhibition. Human liver GP has $80 \%$ sequence identity to rabbit muscle GP (RMGP). All key residues at the AMP, purine and indole sites were found to be conserved between these two isoforms. The only residue substitution of lysine $(\mathrm{K})$ for arginine $(\mathrm{R})$ in HLGP and RMGP 
respectively was found within the purine site at residue 641. This is insignificant as far as functionality is concerned. Next, individual docking of 5, 7, 9-13 and 19 was carried out at the primary inhibitor binding sites of HLGP; AMP, purine and indole binding sites. Although weak binding across all sites was observed, with Cscores in the range 4.0 to 6.7, Cscores for $5,7,9-13$ and 19 were generally closer in magnitude to the value obtained for the docked ligand $\mathbf{3 0}$ at the purine site. However, site specificity cannot be confirmed due to the small differences between the site CScore values. Visual inspection of compounds 5, 7, 9-13 and 19 at the AMP, purine and indole binding sites revealed interesting interactions with HGLP.

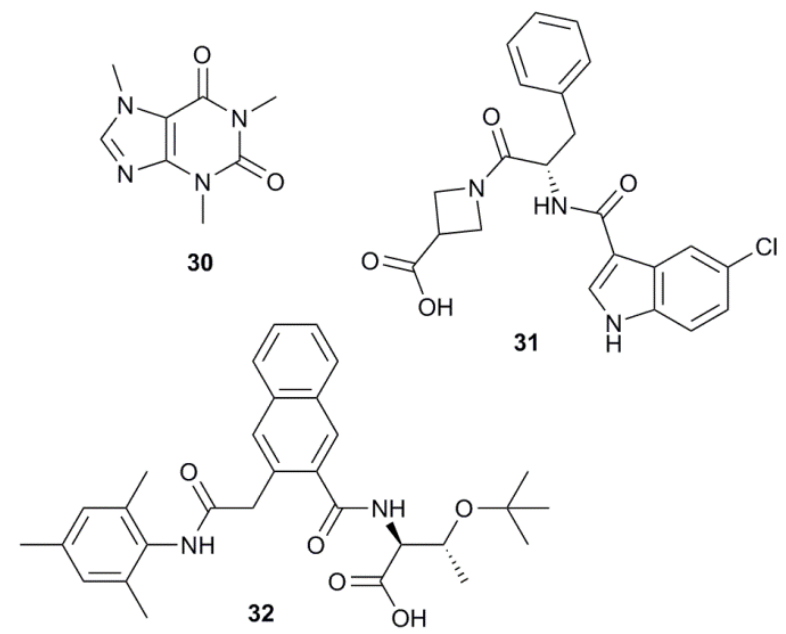

Fig. 3. Structures of docking ligands $\mathbf{3 0}, \mathbf{3 1}$ and $\mathbf{3 2}$.

The AMP site is located at the subunit interface on the regulatory face of HLGP. Polar interactions are important at this site. Compounds 19,9 and 7, which had larger TPSA's and more flexibility, displayed a degree of binding affinity at the AMP site. Compounds $\mathbf{9}$ and $\mathbf{1 9}$ were oriented with their heterocyclic ring directed outwards towards the polar peptide bond atoms of GLN71 with their alkyl chains in toward a more hydrophobic region in front of TRP67 (compound 9; Fig. 4). A hydrogen bond was observed between ASP42 and the carbonyl oxygen atom of $\mathbf{1 9}$ while the same group on $\mathbf{9}$ made a hydrogen bond with GLN71. 

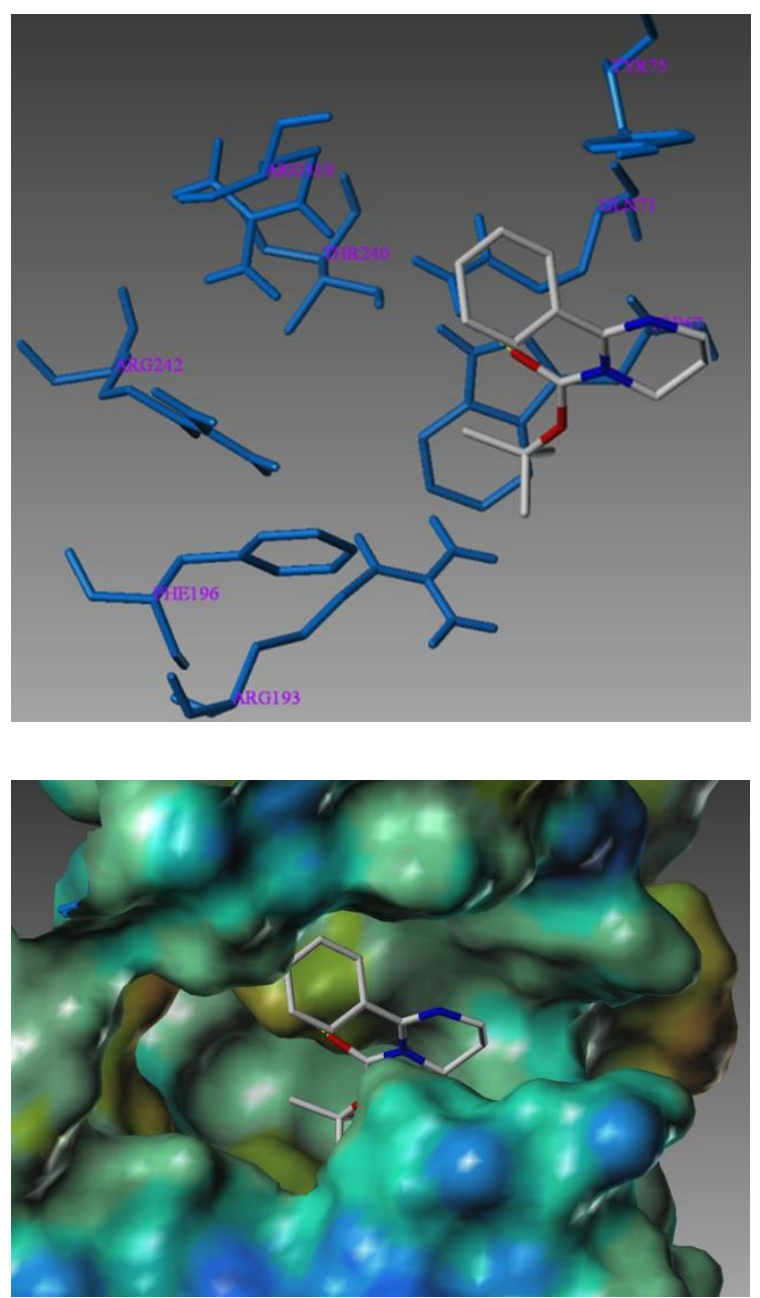

Fig. 4. Compound 9 docked into the AMP binding site of HLGP. Binding site key interactions (top, compound 9 in atom colours and residues in blue) and Molcad surface (bottom, coloured by lipophilic character: blue, polar; brown, nonpolar). Yellow lines indicate hydrogen bonding.

By comparison, thiazoline 7 displayed two hydrogen bonds to GLN71 and THR240. The benzene ring was positioned in the hydrophobic region around ILE68. Whereas, hexahydro1H-benzimidazole 13 appeared to be flipped such that its fused ring is pointing out of the site forcing the benzene ring into a slightly polar area. The key interactions driving the positioning of $\mathbf{1 3}$ appeared to be the two hydrogen bonds to ARG310. Compounds $\mathbf{5}$ and $\mathbf{1 2}$ were located in a similar position to each other with their heterocyclic rings oriented towards a small polar pocket to one side of the main site. Tetrahydropyrimidine $\mathbf{1 1}$ was also in a similar binding orientation despite the addition of the 2 methyl groups of the heterocyclic ring para to the benzene ring. A hydrogen bond between GLN71 and the heterocyclic N steered 
the ring outward from the polar pocket. The smaller spatial capacity of the AMP site restricted access of the larger fused ring of 13, as compared to compounds $\mathbf{1 1}$ and $\mathbf{1 2}$.

Inhibition at the purine site stabilises the $\mathrm{T}$ state. Other studies have demonstrated that heteroaromatic rings are preferred at this site [59]. Key interactions are hydrophobic in nature and include pi stacking between the aromatic rings of TYP613 and PHE285. The docking results for compounds 5, 7, 9-13 and 19 support this finding. Compounds 5, 9, and 11 showed a slight preference for the purine site, as indicated by comparison of Cscore values for each site.

Overall the heterocyclic ring of each compound favours pi stacking in between the rings of TYR613 and PHE285, with approximately $8 \AA$ separating the rings of these two residues. The heterocyclic ring docked consistently midway between them, as illustrated by tetrahydropyrimidine 11 (Fig. 5).
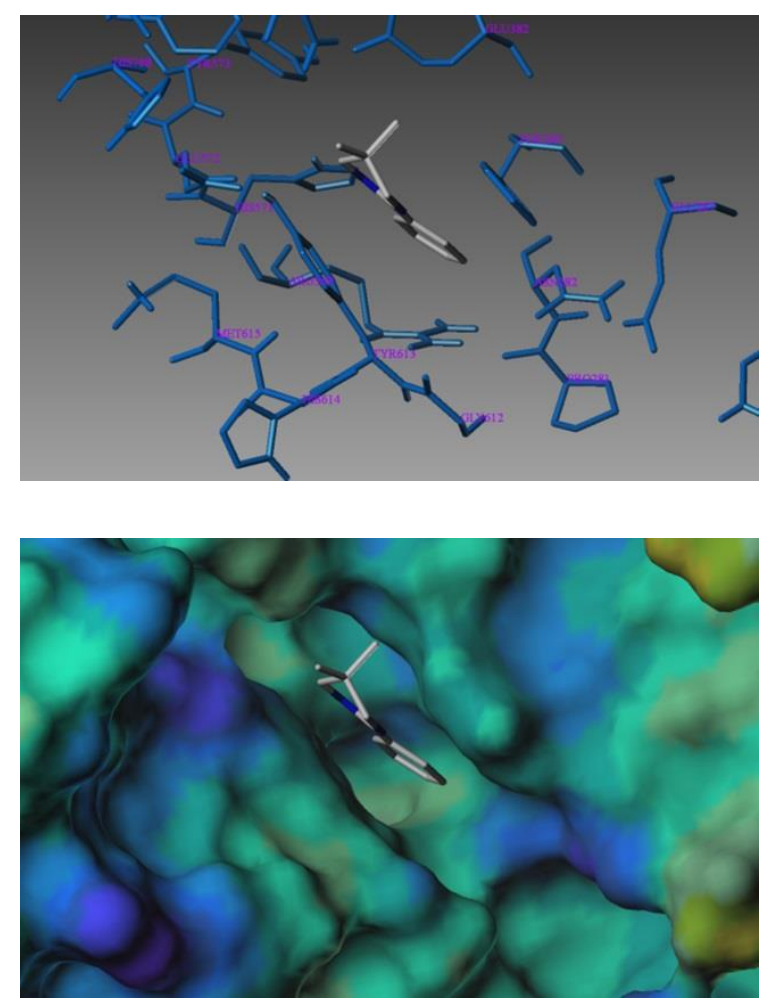

Fig 5. Compound 11 docked into the purine binding site of HLGP. Binding site key interactions (top, compound $\mathbf{1 1}$ in atom colours and residues in blue) and Molcad surface (bottom, coloured by lipophilic character: blue, polar; brown, nonpolar). 
This interaction was maximised in the docked conformation of 7 (Fig. 6) in the purine binding site, where thiazoline 7 was situated in between the rings of TYR613 and PHE285 as a result of key pi stacking interactions. In addition two hydrogen bonds were observed between the lone pairs on the ester oxygen atoms of 7 with the imidazole NH of HIS571. Despite these polar interactions, 7 had a lower docking score than $\mathbf{9}$, the highest scoring compound at the purine site. The tetrahydropyrimidine ring of 9 and morpholine ring of 19 was bound such that it maximised pi stacking interactions between PHE285 and TYR613. Furthermore, the polar amine group of $\mathbf{1 9}$ takes advantage of hydrogen bonding to the side chains of GLU382 and TYR613 while the alkyl group was directed towards the solvent space. These additional interactions contributed to the higher binding affinity of $\mathbf{1 9}$ at the purine site.
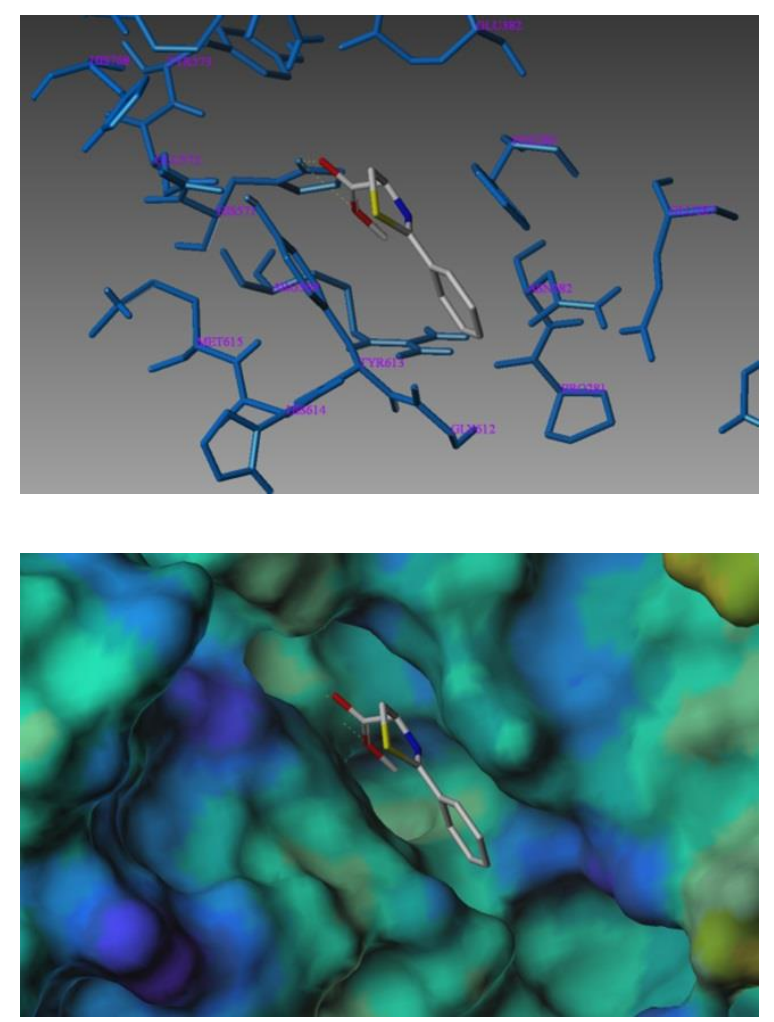
Fig. 6. Compound 7 docked into the purine site of HLGP. Binding site key interactions (top, compound 7 in atom colours and residues in blue) and Molcad surface (bottom, coloured by lipophilic character: blue, polar; brown, nonpolar). Yellow lines indicate hydrogen bonding.

Steric factors appeared not to impact as much on the total score in the purine site due to the small size of the compounds compared to the available space within the purine site. Introduction of a 7-membered heterocyclic ring, as in $\mathbf{5}$ and 12, had the effect of preventing the heterocyclic ring from entering the site resulting in a superficial interaction. Studies have shown that compounds which are able to access the more buried hydrophobic area within this site have higher inhibitory activity [7].

The indole site has hydrophilic character along the length of this $30 \AA$ solvent-filled channel and fluctuates between more hydrophilic areas towards each end as well as in the centre around ARG60 and ASN187 interspersed with a number of hydrophobic 'hotspots'. The backbone structure of 31, a selective ligand for the indole site, alternates between hydrophobic and hydrophilic character thus mimicing that of the channel. As a result, 31 binds strongly into the indole site with nanomolar activity [7].

At the indole site morpholine $\mathbf{1 9}$ was the highest binding compound and was oriented with its heterocyclic ring in a hydrophobic area created by the alkyl R group of LYS191. One hydrogen bond was observed between the peptide oxygen atom of TYR185 and the amide NH. The heterocyclic ring of $\mathbf{9}$, the second highest scoring compound, was shifted to exploit a polar hydrogen bonding interaction with the R group amine of LYS191. The benzene ring of 9 was directed towards the hydrophobic pocket while the BOC group was situated between the polar region created ARG60 of chain A and ARG60' of chain B.

Compounds 12 and 13 were observed to bind further towards one end of the channel with the fused ring of hexahydro-1H-benzimidazole 13 placed further inwards into the channel. The two nitrogens on the heterocyclic ring made the same two hydrogen bonds to HIS57 and ARG61' of chain B (Fig. 7). Despite the relatively small difference in structure to $\mathbf{1 2}$ and $\mathbf{1 3}$, 12 was transposed in relation to the hydrogen bonding interactions to the HIS57' of chain B and ARG61 of chain A. Introducing an oxygen atom into the heterocyclic ring, as in 5, repositions the compound within the channel to where the oxygen atom could hydrogen bond with the amine R group of LYS191. This compares to the lack of change in compound orientation within the AMP or purine sites when the heteroatom structural change was introduced. 

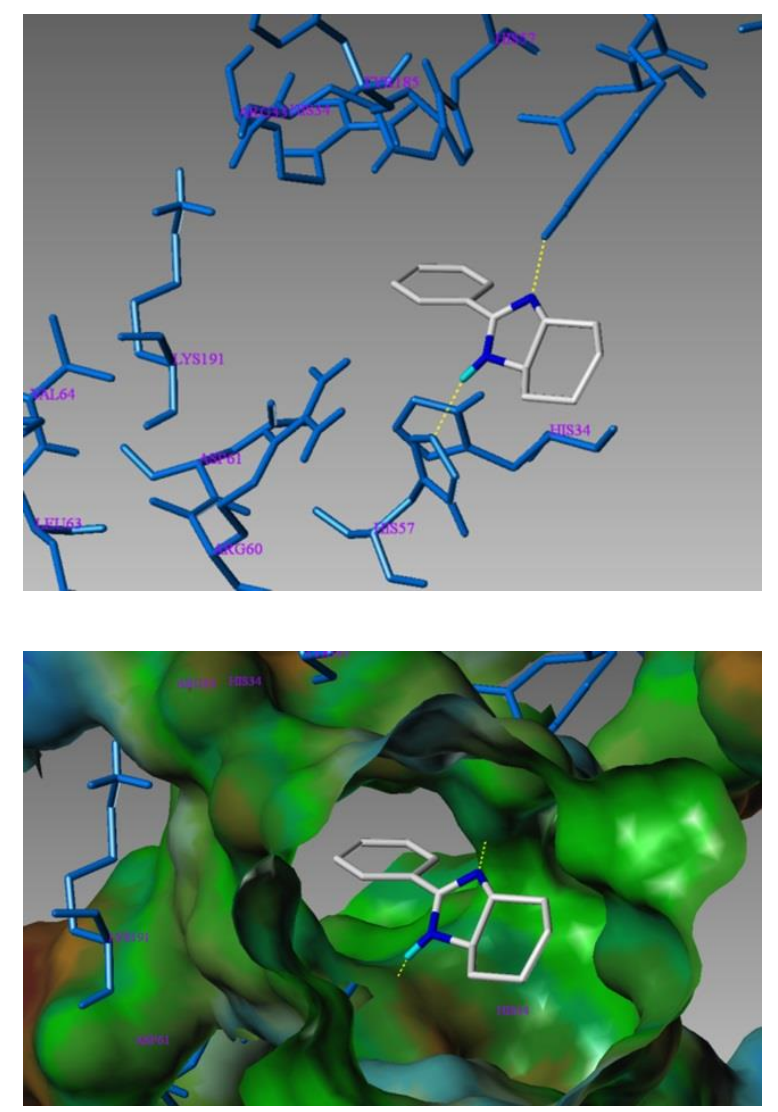

Fig. 7. Compound 13 docked into the indole site of HLGP. Binding site interactions (top, Compound $\mathbf{1 3}$ in atom colours and residues in blue) and Molcad surface of the channel (bottom, coloured by lipophilic character: blue being polar and brown being nonpolar). Yellow lines indicate hydrogen bonding.

\section{Conclusion}

New heterocyclic inhibitors 5, 7, 9 -13 and 19 of GP, with $\mathrm{IC}_{50}<7.8 \mathrm{mM}$ and which met the rule of five (or rule of three), in combination with predicted values for $\log P$ and $\log S$ within suggested limits (compounds 5, 7, 11-13), were identified using a fragment screening approach. Exploration of the molecular interactions of 5, 7, 9-13 and 19 with HLGP in silico, revealed moderate binding to the AMP, indole and purine binding sites of GP and generally non-specific site binding to GP. This is not unexpected due to the low molecular weight of the compounds. The heterocyclic atoms within compounds 5, 7, 9-13 and 19 were a key contributor to exploiting polar interactions such as hydrogen bonding. Tetrahydropyrimidine 9 and morpholine 19, displayed the strongest non-specific binding across the binding sites due to their increased flexibility, yet are compromised as potential hits by non-specificity and poorer values for predicted $\log \mathrm{P}$ (compound 9) or combination of predicted $\log \mathrm{P}$ and $\log \mathrm{S}$ 
(compound 19). Higher total scores (comparable to the site specific inhibitor 30) were observed for compounds 5, 7, 9-12 and 19 for the purine site. However, superficial interactions were observed with $\mathbf{5}$ and $\mathbf{1 2}$ due to the larger heterocyclic ring restricting purine site access. No conclusion can be drawn with confidence regarding the structural preferences for binding to one particular site, but two compounds are of interest. Tetrahydropyrimidine 11 is potentially an interesting hit compound due to the molecular criteria analysis, good potency $\left(\mathrm{IC}_{50}\right.$ of $1.2 \mathrm{mM}$ ) and a tendency for the purine site as indicated by the in silico modelling. Similarly, thiazoline 7 provides an equally good hit from this subset as it met the molecular analysis criteria, displayed an improved potency $\left(\mathrm{IC}_{50}\right.$ of $\left.25 \mu \mathrm{M}\right)$ and had an ambivalent preference for the AMP and purine site over the indole site. In combination with the above results the LE and LELP analysis indicated that compound 7 was a promising hit, with compounds $\mathbf{5}$ and $\mathbf{1 1}$ being second tier hits. Based on these overall results, further design and synthesis of thiazoline derivatives of compound 7 (eg probing spatial and hydrogen bonding interactions) to develop more specific inhibitors for the purine site of GP would be of interest.

\section{Experimental}

All reagents were purchased from commercial suppliers and used without further purification. Samples of compounds 1-13 were synthesised as reported elsewhere [40,41]. Column chromatography was performed using silica gel $60 \AA(0.040-0.063 \mathrm{~mm})$. Analytical thin layer chromatography (TLC) was performed using aluminium plates coated with silica gel 69 F254 $(0.2 \mathrm{~mm})$, and visualized by means of ultra-violet light or vanillin dip. Melting points were measured on a variable temperature apparatus by the capillary method and are uncorrected. High resolution mass spectroscopy (HRMS) was performed on a Fourier Transform Mass Spectrometer equipped with an electrospray source (ESI-FTMS). Mass spectra were recorded using electrospray as the ionization technique. ${ }^{1} \mathrm{H}$ and ${ }^{13} \mathrm{C}$ NMR spectra were recorded in $\mathrm{CDCl}_{3}$ at 300 or $400 \mathrm{MHz}$ and chemical shifts are reported in parts per million, using the appropriate signal for solvent as a reference.

\subsection{Docking studies}

The crystal structure of human liver GP complexed with O-tert-butyl-N-[(3-\{[(2,4,6trimethylphenyl)carbamoyl]amino \}naphthalen-2-yl)carbonyl]-L-threonine $\mathbf{3 2}$ (PDB ID: 3DDS) [58] was used in Surflex-Dock for the AMP binding site. The crystal structure of human liver GPa complexed with caffeine 30 (PDB ID: 1L5Q) [7] at the purine binding site 
and [5-chloro-1H-indol-2-carbonyl-phenylalaninyl]-azetidine-3-carboxylic acid 31 (PDB ID: 1L5Q) [7] at the indole binding site was also used in Surflex-Dock. All X-ray structures were freely accessed from the Protein Data Bank [60]. Prior to docking, the ligands 30, 31 or 32 were extracted from the crystal structures, the structural water molecules were removed and hydrogen atoms were added to the protein. Protonation type was restricted to residues near the binding site (glutamic acids were deprotonated and histidines were protonated); Amber FF99 atoms types were assigned; charges were added using Gasteiger-Hückel method, and the side chain amines and side chain bumps were fixed. The protomol threshold value was set to $0.10 \AA$ and bloat was set to $2 \AA$. All the other parameters were set to the default value.

The initial conformations of compounds 5, 7, 9-13 and 19 were optimized in SYBYL-X 2.0 [61]. Hydrogen's were added and Gasteiger-Hückel charges were assigned to the atoms. The structures were minimized using the Conjugate Gradient method with the Amber7FF94 force field to reach a final energy convergence gradient value of $0.05 \mathrm{kcal} / \mathrm{mol}$. The minimized structures offered reasonable starting conformations for docking. The Surflex-Dock program [62,63] interfaced with SYBYL-X 2.0, was used to dock compounds 5, 7, 9-13 and 19 to each of the GP binding domains, AMP (allosteric), purine and indole (new allosteric). An overlay of compounds 5, 7, 9-13 and 19 docked in each of the AMP, purine and indole sites indicated that none of $\mathbf{5}, \mathbf{7}, \mathbf{9 - 1 3}$ and 19 were sitting outside the binding site, thus eliminating false positive results for the Cscore.

\subsection{Computational Studies.}

8.2.1. Ligand Efficiency (LE). Ligand Efficiency [57] was calculated for a temperature of $300 \mathrm{~K}$ using the following equation.

$$
L E=\Delta g=(\Delta G) / N
$$

where $\Delta \mathrm{G}=-\mathrm{RT} \ln K_{\mathrm{d}}$ and $\mathrm{N}$ is the number of non-hydrogen atoms. The units used for LE were units $\mathrm{kcal} / \mathrm{mol}$ per non-hydrogen atom. Following the practice of substitution of $\mathrm{pK}_{\mathrm{d}}$ with $\mathrm{pIC}_{50}$, LE can be expressed as $\mathrm{LE}=(1.37 / \mathrm{HA}) \times \mathrm{pIC}_{50}$ [57]. pIC50 values were calculated from the $\mathrm{IC}_{50}$ values [64]. The $\mathrm{LE}$ values were comparable as the assay conditions were the same for all tested compounds.

\subsubsection{Ligand-Efficiency-dependent Lipophilicity (LELP). Ligand-Efficiency-dependent}

Lipophilicity [65] was calculated for compounds using the definition of LELP $=$ the ratio of $\log \mathrm{P}$ and ligand efficiency (LE). 


\subsection{Typical procedure for $\mathrm{N}$-protection ( $\mathrm{Cbz}$ ) of amino acid}

A solution of Phe-OH 22 (5.0 g, 30 mmol, 1.0 equiv) was dissolved in $\mathrm{NaOH}(2 \mathrm{M}, 50 \mathrm{~mL})$ and stirred at $0{ }^{\circ} \mathrm{C}$ under an atmosphere of nitrogen. Benzylchloroformate $(4.3 \mathrm{~mL}, 30 \mathrm{mmol}$, 1.0 equiv) was dissolved in toluene $(5 \mathrm{~mL})$ and $\mathrm{NaOH}(4 \mathrm{M}, 5 \mathrm{~mL})$ was added. The reaction was stirred vigorously at $\mathrm{rt}$ for 30 mins. Water $(50 \mathrm{~mL})$ was added and the mixture extracted with diethyl ether $(2 \times 50 \mathrm{~mL})$. The combined organic layers were cooled to $0{ }^{\circ} \mathrm{C}$ and acidified to $\mathrm{pH} 1$ with $\mathrm{HCl}$ (conc). A white solid formed which was isolated by filtration. The solid was dissolved in DCM $(200 \mathrm{~mL})$. The DCM layer was extracted with brine $(50 \mathrm{~mL})$, dried ( $\mathrm{MgSO}_{4}$, anhydrous) and concentrated in vacuo.

8.3.1. N-[(benzyloxy)carbonyl]phenylalanine 23. A white solid (5.482 g, $60 \%)$. mp 135-136 ${ }^{\circ} \mathrm{C}$, (Lit [66]. mp 130-132 $\left.{ }^{\circ} \mathrm{C}\right)$. ESI-MS m/z $322\left(\mathrm{M}+\mathrm{Na}^{+}\right), 300\left(\mathrm{M}+\mathrm{H}^{+}\right)$.

8.3.2. N,N-[(benzyloxy)carbonyl]lysine 25 [67]. Using benzylchloroformate (60 mmol) and purification by silica column chromatography (ethyl acetate:hexane, 40:60). A clear oil (8.9 g, $72 \%$ ). ESI-MS m/z $437\left(\mathrm{M}+\mathrm{Na}^{+}\right), 415\left(\mathrm{M}+\mathrm{H}^{+}\right) .{ }^{1} \mathrm{H}$ NMR $\left(400 \mathrm{MHz}, \mathrm{CDCl}_{3}\right) \delta$ : 7.6 (brs, $\left.1 \mathrm{H}, \mathrm{W}_{\mathrm{h} / \mathrm{z}}=58 \mathrm{~Hz}, \mathrm{OH}\right), 7.30\left(\mathrm{~m}, 10 \mathrm{H}, 2 \times \mathrm{C}_{6} \mathrm{H}_{5}\right), 6.35$ (brs, $\left.1 \mathrm{H}, \mathrm{W}_{\mathrm{h} / \mathrm{z}}=19 \mathrm{~Hz}, \mathrm{NH}\right)$, 5.00-5.20 (m, 4H, $\left.2 \times \mathrm{CH}_{2}\right), 4.20-4.39(\mathrm{~m}, 1 \mathrm{H}, \alpha \mathrm{CH}), 3.05-3.20\left(\mathrm{~m}, 2 \mathrm{H}, \varepsilon \mathrm{CH}_{2}\right), 1.79-1.90$ (m, $1 \mathrm{H}, \beta \mathrm{CH}), 1.66-1.79(\mathrm{~m}, 1 \mathrm{H}, \beta \mathrm{CH}), 1.40-1.50\left(\mathrm{~m}, 2 \mathrm{H}, \delta \mathrm{CH}_{2}\right), 1.30-1.40\left(\mathrm{~m}, 2 \mathrm{H}, \gamma \mathrm{CH}_{2}\right)$.

8.3.3. N-[(benzyloxy)carbonyl]leucine 27 [68]. Using Leu-OH 26 (38 mmol). A clear oil $(8.022 \mathrm{~g}, 79 \%)$. ESI-MS $m / z 288\left(\mathrm{M}+\mathrm{Na}^{+}\right), 266\left(\mathrm{M}+\mathrm{H}^{+}\right) .{ }^{1} \mathrm{H}$ NMR $\left(400 \mathrm{MHz}, \mathrm{CDCl}_{3}\right) \delta$ : 7.33 (m, 5H, ArH), 5.10 (s, 2H, $\left.\mathrm{CH}_{2} \mathrm{Ar}\right), 4.30-4.40(\mathrm{~m}, 1 \mathrm{H}, \alpha \mathrm{CH}), 1.60-1.80\left(\mathrm{~m}, 2 \mathrm{H}, \beta_{\mathrm{CH}}\right)$, 1.46-1.60 (m, 1H, $\gamma \mathrm{CH}), 0.90\left(\mathrm{~s}, 6 \mathrm{H}, 1 \times \gamma \mathrm{CH}_{3}, \delta \mathrm{CH}_{3}\right)$.

\subsection{Typical procedure for coupling morpholine with amino acid}

HOBt (959 mg, $7.10 \mathrm{mmol}, 0.85$ equiv) and $\mathrm{EDC} . \mathrm{HCl}$ (1.6 g, $8.36 \mathrm{mmol}, 1.0$ equiv) were dissolved in DCM (anhydrous, $50 \mathrm{~mL}$ ). Z-Phe-OH 23 (2.5 g, $8.36 \mathrm{mmol}, 1.0$ equiv) was added and the mixture stirred for 4 hrs under an atmosphere of nitrogen. Morpholine $(1.09 \mathrm{~g}$, $12.54 \mathrm{mmol}, 1.5$ equiv) and DIPEA (2.7 g, $20.9 \mathrm{mmol}, 2.5$ equiv) were added and the reaction stirred for $20 \mathrm{hrs}$. The reaction mixture was washed with water $(50 \mathrm{~mL})$. The organic layer was extracted with brine $(50 \mathrm{~mL})$, dried $\left(\mathrm{MgSO}_{4}\right.$, anhydrous $)$ and concentrated in 
vасио. The residue was purification of the residue by silica column chromatography (ethyl acetate:hexane).

8.4.1. Benzyl-1-morpholino-1-oxo-3-phenylpropan-2-ylcarbamate 14 [69]. Purification (ethyl acetate:hexane, 55:45). A beige gum (2.35 g, $79.5 \%)$. ESI-MS $m / z 391\left(\mathrm{M}+\mathrm{Na}^{+}\right), 369(\mathrm{M}+$ $\left.\mathrm{H}^{+}\right) .{ }^{1} \mathrm{H}$ NMR (400 MHz, $\left.\mathrm{CDCl}_{3}\right) \delta: 7.13-7.30(\mathrm{~m}, 10 \mathrm{H}, \mathrm{Ar}-\mathrm{H}), 6.20(\mathrm{~d}, 1 \mathrm{H}, J=9 \mathrm{~Hz}, \mathrm{NH})$, $5.20\left(\mathrm{q}, 2 \mathrm{H}, J=9,11.5 \mathrm{~Hz}, \mathrm{CH}_{2} \mathrm{Ar}\right), 4.92(\mathrm{dd}, 1 \mathrm{H}, J=5,9 \mathrm{~Hz}, \mathrm{H} 2), 3.50-3.55(\mathrm{~m}, 2 \mathrm{H}, 2 \mathrm{x}$ H6'), 3.29-3.45 (m, 3H, H5', 2 x H2'), 3.19-3.29 (m, 1H, H5'), 2.87-3.05 (m, 3H, H3, 2 x H3'), 2.77-2.87 (m, 1H, H3).

8.4.2. Benzyl, N-(benzyloxy)-1-Morpholino-1-oxohexan-2-ylcarbanmate 16. Using Z-Lys(Z)OH 25 (2.928 g, 7.07 mmol, 1.0 equiv) and purification with ethyl acetate:hexane, 80:20. A clear oil (1.337 g, $39 \%) .{ }^{1} \mathrm{H}$ NMR $\left(400 \mathrm{MHz}, \mathrm{CDCl}_{3}\right) \delta: 7.30$ (s, 10H, ArH), 5.8-6.0 (brs, 2H, 2-NH, 6-NH), 4.95-5.13 (m, 4H, 2-NHC(O)OCH $\left.2,6-\mathrm{NHC}_{2}(\mathrm{O}) \mathrm{OCH}_{2}\right), 4.5-4.59(\mathrm{~m}, 1 \mathrm{H}$, H2), 3.64-3.68 (m, 5H, 2 x H2', H5', 2 x H6'), 3.56-3.64 (m, 3H, H5', 2 x H3'), 3.02-3.20 (m, 2H, 2 x H6), 1.58-1.72 (m, 1H, H3), 1.40-1.58 (m, 2H, H5, H3), 1.22-1.40 (m, 2H, H4, H5), 1.14-1.22 (m, 1H, H4). ${ }^{13} \mathrm{C}$ NMR (75 MHz, $\left.\mathrm{CDCl}_{3}\right) \delta: 170.3,156.3,156.0,156.5$, 156.3, 128.3 (3C), 127.9 (2C), 127.9 (2C), 127.8 (3C), 67.2, 67.0, 66.8 (2C), 49.2, 46.4, 42.8, 40.8, 33.0, 29.1, 22.4. ESI-MS $m / z 506\left(\mathrm{M}+\mathrm{Na}^{+}\right), 484\left(\mathrm{M}+\mathrm{H}^{+}\right)$. HRMS $m / z 484.2426$ (calcd for $\mathrm{C}_{26} \mathrm{H}_{33} \mathrm{~N}_{3} \mathrm{O}_{6}+1 \mathrm{H}, 484.2448$ ).

8.4.3. Benzyl 4-methyl-1-morpholino-1-oxopentan-2-ylcarbamate 18 [70]. Using Z-Leu-OH 27 (2.5 g, $9.43 \mathrm{mmol}, 1.0$ equiv) and purification with ethyl acetate:hexane, 55:45. A colourless oil (3.133 g, $99.5 \%) .{ }^{1} \mathrm{H}$ NMR (400 MHz, $\left.\mathrm{CDCl}_{3}\right) \delta: 7.22$ (m, 5H, ArH), 5.98 ( d, 1H, NH), 5.00 (s, 2H, $\mathrm{CH}_{2} \mathrm{Ar}$ ), 4.55-4.65 (m, 1H, 1 x H2), 3.42-3.62 (m, 6H, 2 x H5', 2 x H2', 1 x H6'), 3.32-3.42 (m, 2H, 2 x H3'), 1.58-1.70 (m, 1H, 1 x H3), 1.41-1.52 (m, 1H, 1 x H3), 1.30-1.39 (m, 1H, 1 x H4), 0.90 (d, 3H, J = 6.5 Hz, 3 x H5), 0.85 (d, 3H, J = $6.5 \mathrm{~Hz}$, 4- $\left.\mathrm{CH}_{3}\right) .{ }^{13} \mathrm{C} \mathrm{NMR}\left(100 \mathrm{MHz}, \mathrm{CDCl}_{3}\right) \delta: 170.2,155.9,135.7,129.8$ (2C), 128.4, 127.2 (2C), 67.1, 67.0, 66.9, 49.0, 46.3, 42.7, 24.9, 23.6 (2C), 23.2. ESI-MS $m / z 357\left(\mathrm{M}+\mathrm{Na}^{+}\right), 335(\mathrm{M}$ $\left.+\mathrm{H}^{+}\right)$.

8.4.4. tert-Butyl 4-((benzyloxy) carbonyl)-1-morpholino-1-oxobutan-2-ylcarbamate 29. Using Boc-Glu(OBzl)-OH 28 (2.0 g, $5.92 \mathrm{mmol}, 1.0$ equiv) and purification with ethyl acetate:hexane, 50:50. A clear oil (1.213 g, $50 \%)$. ${ }^{1} \mathrm{H}$ NMR (300 $\left.\mathrm{MHz}, \mathrm{CD}_{3} \mathrm{OD}\right) \delta$ : 
7.15-7.35 (m, 5H, ArH), $5.59(\mathrm{dd}, 1 \mathrm{H}, J=9.7 \mathrm{~Hz}, 1 \times \mathrm{NH}), 4.90-5.15(\mathrm{~m}, 2 \mathrm{H}, 2$ x $\mathrm{CH}_{2} \mathrm{C}_{6} \mathrm{H}_{5}$ ), 4.50-4.63 (m, 1H, H2), 3.39-3.61 (m, 8H, 2 x H2', 2 x H3', 2 x H5', 2 x H6'), 2.05-2.50 (m, 2H, 2 x H4), 1.82-2.00 (m, 1H, H3), 1.52-1.70 (m, 1H, H3), 1.30 (s, 9H, 3 x $\left.\mathrm{CH}_{3}\right) .{ }^{13} \mathrm{C} \mathrm{NMR}\left(75 \mathrm{MHz}, \mathrm{CD}_{3} \mathrm{OD}\right) \delta: 172.4,170.1,155.4,135.5,128.2$ (2C), 127.9 (3C), 79.2, 66.3, 66.3, 59.9, 48.7, 45.5, 42.1, 29.1, 28.1, 28.1, 20.6, 13.86. ESI-MS m/z 407 (M + $\mathrm{Na}^{+}$). HRMS $m / z 407.2168$ (calcd for $\mathrm{C}_{21} \mathrm{H}_{30} \mathrm{~N}_{2} \mathrm{NaO}_{6}+1 \mathrm{H}, 407.2176$ ).

\subsection{Typical procedure for $N$-deprotection}

Z-Phe-Morpholine $14(732 \mathrm{mg})$ was dissolved in ethanol (30 mL) and added to palladiumon-carbon (140 mg, $10 \%)$ under an atmosphere of nitrogen. Ethanol (30 mL) and acetic acid (97.8 $\mu \mathrm{m}, 1.5$ equiv) were added. The reaction was placed under an atmosphere of hydrogen and stirred for $48 \mathrm{hrs}$. The reaction was quenched with nitrogen gas and celite, filtered and the residue washed. Removal of the solvent in vacuo gave the product.

8.5.1. 1-Morpholin-4-yl-1-oxo-3-phenylpropan-2-amine 15 [71]. A beige oil (893 mg, $79 \%$ ), characterised as the acetate salt. ${ }^{1} \mathrm{H} \mathrm{NMR}\left(300 \mathrm{MHz}, \mathrm{CDCl}_{3}\right) \delta: 7.38\left(\mathrm{~s}, 3 \mathrm{H}, 1 \mathrm{x} \mathrm{N_{3 }}{ }^{+}\right)$, 6.96-7.22 (m, 5H, $\mathrm{C}_{6} \mathrm{H}_{5}$ ), 3.89-4.48 (m, 1H, H2), 3.38-3.61 (m, 2H, 2 x H6'), 3.18-3.38 (m, 3H, H5', 2 x H2'), 3.08-3.18 (m, 1H, H5'), 2.92-3.08 (m, 1H, H3'), 2.80-2.92 (m, 1H, H3'), 2.60-2.80 (m, 2H, 2 x H3), $1.83\left(\mathrm{~s}, 3 \mathrm{H}, \mathrm{C}(\mathrm{O}) \mathrm{CH}_{3}\right) .{ }^{13} \mathrm{C} \mathrm{NMR}\left(75 \mathrm{MHz}, \mathrm{CDCl}_{3}\right)$ 8: 176.6, 170.2, 135.6, 129.3 (2C), 128.3 (2C), 127.0, 65.9, 65.5, 50.4, 45.5, 41.9, 40.2, 22.4. ESI-MS $m / z 235\left(\mathrm{M}+\mathrm{H}^{+}\right)$. HRMS $m / z 235.1448$ (calcd for $\mathrm{C}_{13} \mathrm{H}_{18} \mathrm{~N}_{2} \mathrm{O}_{2}+1 \mathrm{H}, 235.1441$ ).

8.5.2. 6-Morpholin-4'-yl-6-oxohexan-1,5-diamine 17 [72]. A beige oil (525 mg, 87 \%), characterised as the diacetate salt. ${ }^{1} \mathrm{H}$ NMR $\left(300 \mathrm{MHz}, \mathrm{CDCl}_{3}\right) \delta: 8.90\left(\mathrm{~s}, 6 \mathrm{H}, 2 \mathrm{x} \mathrm{NH}_{3}{ }^{+}\right)$, 3.99-4.40 (m, 1H, H5), 3.49-3.66 (m, 5H, 2 x H6', 2 x H2'), 3.23-3.49 (m, 3H, H3', 2 x H5'), 2.60-2.98 (m, 3H, 2 x H1, H3'), 1.73-1.98 (s, 7H, 2 x C(O)CH3, $\mathrm{H} 4), 1.51-1.73$ (m, $3 \mathrm{H}, \mathrm{H} 3,2$ x H2), 1.43-1.51 (m, 1H, H3), 1.13-1.23 (m, 1H, H3). ${ }^{13} \mathrm{C}$ NMR (75 MHz, $\left.\mathrm{CDCl}_{3}\right)$ $\delta: 177.3$ (2C), 168.8, 66.5, 66.3, 57.6, 49.5, 45.8, 42.5, 38.4, 30.5, 26.6, 22.9. ESI-MS $m / z$ $216\left(\mathrm{M}+\mathrm{H}^{+}\right)$. HRMS m/z,238.1532 (calcd for $\mathrm{C}_{10} \mathrm{H}_{21} \mathrm{~N}_{3} \mathrm{O}_{2}+\mathrm{Na}, 238.1531$ ).

8.5.3. 4-Methyl-1-morpholin-4-yl-1-oxopentan-2-amine 19 [72]. Using ethyl acetate as reaction solvent. A beige oil (300 mg, $88 \%)$. ${ }^{1} \mathrm{H}$ NMR (300 MHz, $\left.\mathrm{CDCl}_{3}\right) \delta:$ 4.50-4.57 (m, 1H, 1 x H2), 3.55-3.92 (m, 6H, 2 x H3', 2 x H5', 2 x H6'), 3.39-3.55 (m, 2H, 2 x H2'), 1.78-1.98 (m, 2H, 1 x H4, 1 x H3), 1.47-1.54 (m, 1H, 1 x H3), 0.90-1.05 (m, 6H, 3 x H5, 
4- $\left.\mathrm{CH}_{3}\right), \mathrm{NH}_{2}$ not observed. ${ }^{13} \mathrm{C} \mathrm{NMR}\left(75 \mathrm{MHz}, \mathrm{CDCl}_{3}\right) \delta: 169.2,66.4,66.3,49.1,46.2,42.8$, 40.7, 24.2, 23.1, 22.0. ESI-MS $m / z 201\left(\mathrm{M}+\mathrm{H}^{+}\right)$. HRMS $m / z 201.1589$ (calcd for $\left.\mathrm{C}_{10} \mathrm{H}_{20} \mathrm{~N}_{2} \mathrm{O}_{2}+1 \mathrm{H}, 201.1598\right)$.

8.5.4 4-(tert-Butoxycarbonyl) amino-5-morpholino-5-oxopentanoic acid 20. Using ethyl acetate as reaction solvent. A white gum (650 mg, $93 \%) .{ }^{1} \mathrm{H} \mathrm{NMR}\left(300 \mathrm{MHz}, \mathrm{CD}_{3} \mathrm{OD}\right) \delta$ : 8.4 (br s, OH), 5.57 (dd, 1H, J = 11.9 Hz, NH), 4.60-4.72 (m, 1H, H4), 3.60 (s, 8H, 2 x H2', 2 x H3', 2 x H5', 2 x H6'), 2.23-2.57 (m, 2H, 2 x H2), 1.87-2.07 (m, 1H, H3), 1.52-1.77 (m, 1H, H3), 1.34 (s, 9H, $\left.3 \times \mathrm{CH}_{3}\right) .{ }^{13} \mathrm{C} \mathrm{NMR}\left(75 \mathrm{MHz}, \mathrm{CD}_{3} \mathrm{OD}\right) \delta: 176.4,170.6,155.9,80.0$, 66.6 (2C), 49.0, 45.9, 42.5, 29.1, 28.2 (3C), 20.6. ESI-MS m/z $317\left(\mathrm{M}+\mathrm{H}^{+}\right)$. HRMS $\mathrm{m} / \mathrm{z}$ 317.1714 (calcd for $\mathrm{C}_{14} \mathrm{H}_{24} \mathrm{~N}_{2} \mathrm{O}_{6}+1 \mathrm{H}, 317.1707$ ).

8.5.5. 4-Amino-5-morpholino-5-oxopentanoic acid 21 [72]. Boc-Glu-morpholine 20 (498 mg) was dissolved in $\mathrm{HCl} / \mathrm{ether}\left(4.7 \mathrm{~mL}, 3\right.$ equiv) and methanol (4 mL, anhydrous) at $0{ }^{\circ} \mathrm{C}$ under an atmosphere of nitrogen. The reaction was stirred at $\mathrm{rt}$ for $2 \mathrm{hrs}$. The solution was extracted with ethyl acetate and the solvent was removed in vacuo. A beige oil $(272 \mathrm{mg}, 80 \%)$. ${ }^{1} \mathrm{H}$

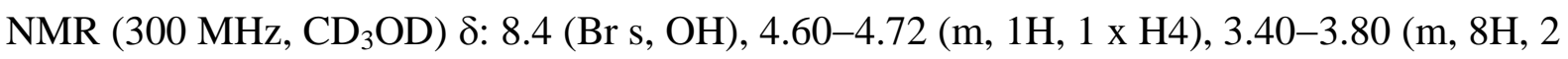
x H2', 2 x H3', 2 x H5', 2 x H6'), 2.50-2.70 (m, 2H, 2 x H3), 2.00-2.22 (m, 2H, 2 x H2). ${ }^{13} \mathrm{C}$ NMR (75 MHz, CD $\left.{ }_{3} \mathrm{OD}\right) \delta: 174.3,168.3,67.5$ (2C), 52.5, 47.1, 43.8, 29.3, 26.6. ESI-MS m/z $239\left(\mathrm{M}+\mathrm{Na}^{+}\right)$. HRMS $m / z, 239.1009$ (calcd for $\mathrm{C}_{9} \mathrm{H}_{16} \mathrm{~N}_{2} \mathrm{O}_{4}+\mathrm{Na}, 239.1002$ ).

\subsection{GPa Enzyme Assay}

Rabbit Muscle Glycogen Phosphorylase a (from Sigma, 0.475ug/mL) activity was measured in the direction of glycogen synthesis by the release of phosphate from glucose-1-phosphate [55] using a 384 well plate at $22^{\circ} \mathrm{C}$ in $45 \mu \mathrm{l}$ of buffer containing $50 \mathrm{mM}$ Hepes (pH 7.2), 100 $\mathrm{mM} \mathrm{KCl}, 2.5 \mathrm{mM}$ EGTA, $2.5 \mathrm{mM} \mathrm{MgCl}_{2}, 0.25 \mathrm{mM}$ glucose-1-phosphate, and $1 \mathrm{mg} / \mathrm{ml}$ glycogen with a 30 min incubation time. Phosphate was measured at $620 \mathrm{~nm}, 5 \mathrm{~min}$ after the addition of $150 \mu \mathrm{l}$ of $1 \mathrm{M} \mathrm{HCl}$ containing $10 \mathrm{mg} / \mathrm{ml}$ ammonium molybdate and $0.38 \mathrm{mg} / \mathrm{ml}$ malachite green [56]. Test compounds were added to the assay in $5 \mu 1$ of $14 \%$ DMSO. Compounds were tested against a caffeine standard in 11 point concentration-response curve in duplicate on two separate occasions. Data was analyzed using GraphPad Prism v.4.03. A nonlinear regression (curve fit) analysis with a sigmoidal dose-response equation (variable slope) was applied to generate $\mathrm{IC}_{50}$ and Hill slope values. The reported $\mathrm{IC}_{50}$ had a Hill slope between 0.7 and 1.2 and a $Z$ ' value of $\sim 0.8$. Compounds were screened with maximal 
concentrations of $222 \mathrm{mM}$. The assay was carefully monitored for signs of compound insolubility. The results are presented as mean values from 4 determinations.

\section{Conflict of interest}

None.

\section{Acknowledgments}

This research was supported by the Eskitis Institute, Griffith University and partially from a grant from the Diabetes Australia Research Trust.

\section{Appendix A. Supplementary data}

Supplementary data related to this article can be found at http://

\section{References}

1. N.G. Oikonomakos, Glycogen phosphorylase as a molecular target for type 2 diabetes therapy,Curr. Protein Pept. Sci. 3 (2002) 561-586.

2. B. Henke, S. Sparks, Glycogen phosphorylase inhibitors, Mini-Rev. Med. Chem. 6 (2006) 845-857.

3. J.L. Treadway, P. Mendys, D.J. Hoover, Glycogen phosphorylase inhibitors for treatment of type 2 diabetes mellitus, Expert Opin. Invest. Drugs 10 (2001), 439-454.

4. L. Somsák, K. Czifrak, M. Tóth, E. Bokor, E.D. Chrysina, K.-M. Alexacou, J.M. Hayes, C. Tiraidis, E. Lazoura, D.D. Leonidas, S.E. Zographos, N.G. Oikonomakos, New inhibitors of glycogen phosphorylase as potential antidiabetic agents, Curr. Med. Chem. 15 (2008) 2933-2983.

5. D.J. Hoover, S. Lefkowitz-Snow, J.L. Burgess-Henry, W.H. Martin, S. J. Armento, I.A. Stock, R.K. McPherson, P.E. Genereux, E.M. Gibbs, J.L. Treadway, Indole-2carboxamide inhibitors of human liver glycogen phosphorylase, J. Med. Chem. 41 (1998) 2934-2938. 
6. E.D. Chrysina, A. Chajistamatiou, M. Chegkazi, From structure-based to knowledgebased drug design through X-ray protein crystallography: sketching glycogen phosphorylase binding sites, Curr. Med. Chem. 18 (2011) 2620-2629.

7. J.L Ekstrom, T.A. Pauly, M.D. Carty, W.C. Soeller, J. Culp, D.E. Danley, D.J. Hoover, J.L. Treadway, E.M. Gibbs, R.J. Fletterick, Y.S.N. Day, D.G. Myszka, V.L. Rath, Structure-Activity Analysis of the Purine Binding Site of Human Liver Glycogen Phosphorylase, Chem. Biol. 9 (2002), 915-924.

8. W.H. Martin, D.J. Hoover, S.J. Armento, I.A. Stock, R.K. McPherson, D.E. Danley, R.W. Stevenson, E.J. Barrett, J.L. Treadway, Discovery of a human liver glycogen phosphorylase inhibitor that lowers blood glucose in vivo, Proc. Natl. Acad. Sci.U. S. A. 95 (1998), 1776-1778.

9. V.L. Rath, M. Ammirati, D.E. Danley, J.L. Ekstrom, E.M. Gibbs, T.R. Hynes, A.M. Mathiowetz, R.K. McPherson, T.V. Olson, J.L.Treadway, D. Hoover, Human liver glycogen phosphorylase inhibitors bind at a new allosteric site, J. Chem. Biol. 7 (2000), 677-682.

10. C.M. Lukacs, N.G. Oikonomakos, R.L. Crowther, L-N. Hong, R.U. Kammlott, W. Levin, S. Li, C-M. Liu, D. Lucas-McGady, S. Pietranico, L. Reik, The crystal structure of human muscle glycogen phosphorylase a with bound glucose and AMP: An intermediate conformation with T-state and R-state features, Proteins: Struct., Funct., Bioinf. 63 (2006) 1123-1126.

11. N.G. Oikonomakos, V.T. Skamnaki, K.E. Tsitsanou, N.G. Gavalas, L.N. Johnson, A new allosteric site in glycogen phosphorylase b as a target for drug interactions, Structure (Cambridge, MA, U.S.) 8 (2000) 575-584.

12. J.L. Martin, K. Velugaraja, K. Ross, L.N. Johnson, G.W.J. Fleet, N.G. Ramsden, I. Bruce, M.G. Orchard, N.G. Oikonomakos, A.C. Papageorgiou, D.D. Leonidas, H.S. Tsitoura, Glucose analog inhibitors of glycogen phosphorylase: the design of potential drugs for diabetes, Biochemistry 30 (1991) 10101-10116.

13. S.R. Sprang, E.J. Goldsmith, R. J.; Fletterick, S.G. Withers, N.B. Madsen, Catalytic site of glycogen phosphorylase: structure of the T state and specificity for $\alpha$-Dglucose, Biochemistry 21 (1982) 5364-5371.

14. N. Pinotsis, D.D. Leonidas, E.D. Chrysina, N.G. Oikonomakos, I.M. Mavridis, The binding of $\beta$ - and $\gamma$-cyclodextrins to glycogen phosphorylase b: Kinetic and crystallographic studies, Protein Sci. 12 (2003) 1914-1924. 
15. D.J. Baker, P.L. Greenhaff, J.A. Timmons, Glycogen phosphorylase inhibition as a therapeutic target: a review of the recent patent literature, Expert Opin. Ther. Pat. 16 (2006) 459-466.

16. N. Gaboriaud-Kolar, A-L. Skaltsounis, Glycogen phosphorylase inhibitors: a patent review (2008 - 2012), Expert Opin. Ther. Pat. 23 (2013) 1017-1032.

17. L. Somsák, V. Nagy, Z. Hadady, T. Docsa, P. Gergely, Glucose analog inhibitors of glycogen phosphorylases as potential antidiabetic agents: Recent developments, Curr. Pharm. Des. 9 (2003) 1177-1189.

18. T. Barf, Intervention of hepatic glucose production. Small molecule regulators of potential targets for type 2 diabetes therapy, Mini-Rev. Med. Chem. 4 (2004) 897-908.

19. D.J. Baker, P.L. Greenhaff, A. MacInnes, J.A.Timmons, The experimental type 2 diabetes therapy glycogen phosphorylase inhibition can impair aerobic muscle function during prolonged contraction, Diabetes 55 (2006)1855-1861.

20. N.G. Oikonomakos, L. Somsák, Advances in glycogen phosphorylase inhibitor design, Curr. Opin. Invest. Discov. 9 (2008) 379-395.

21. E.D. Chrysina, The prototype of glycogen phosphorylase, Mini-Rev. Med. Chem. 10 (2010) 1093-1101.

22. W.A. Loughlin, Recent advances in the allosteric inhibition of glycogen phosphorylase, Mini-Rev. Med. Chem. 10 (2010) 1139-1155.

23. W-L. Li, C. Jian, M-H. Luo, L. Han, M. Li, W-L. Li, Recent advances in design of glycogen phosphorylase inhibitors, Curr. Enzyme Inhib. 7 (2011) 259-267.

24. B.R. Henke, Inhibition of glycogen phosphorylase as a strategy for the treatment of type 2 diabetes, RSC Drug Discov. Series 27(New Therapeutic Strategies for Type 2 Diabetes) (2012) 324-365.

25. L.J. Hampson, C. Arden, L. Agius, M. Ganotidis, M.N. Kosmopoulou, C. Tiraidis, Y. Elemes, C. Sakarellos, D.D. Leonidas, N.G. Oikonomakos, Bioactivity of glycogen phosphorylase inhibitors that bind to the purine nucleoside site, Bioorg. Med. Chem. 14 (2006) 7835-7845.

26. M.N. Kosmopoulou, D.D. Leonidas, E.D. Chrysina, G. Eisenbrand, N.G. Oikonomakos, Indirubin- 3'-aminooxy-acetate inhibits glycogen phosphorylase by binding at the inhibitor and the allosteric site. Broad specificities of the two sites, Lett. Drug Des. Discov. 2 (2005) 377-390. 
27. K.G. Rosauer, A.K. Ogawa, C.A. Willoughby, K.P. Ellsworth, W.M. Geissler, R.W. Myers, Q. Deng, K.T. Chapman, G. Harris, D.E. Moller, Novel 3,4-dihydroquinolin2(1H)-one inhibitors of human glycogen phosphorylase a, Bioorg. Med. Chem. Lett. 213 (2003) 4385-4388.

28. A.M. Birch, P.W. Kenny, N.G. Oikonomakos, L. Otterbein, P.Schofield, P.R.O.Whittamore, D.P. Whalley, Development of potent, orally active 1-substituted3,4-dihydro-2-quinolone glycogen phosphorylase inhibitors, Bioorg. Med. Chem. Lett. 17 (2007) 394-399.

29. S.W. Wright, V.L. Rath, P.E. Genereux, D.L. Hageman, C.B. Levy, L.D. McClure, S.C. McCoid, R.K. McPherson, T.M. Schelhorn, D.E. Wilder, W.J. Zavadoski, E.M. Gibbs, J.L. Treadway, 5- Chloroindoloyl glycine amide inhibitors of glycogen phosphorylase: synthesis, in vitro, in vivo, and X-ray crystallographic characterization, Bioorg. Med. Chem. Lett. 15 (2005) 459-465.

30. S. Kun, G.Z. Nagy, M. Tóth, L. Czecze, A.N. Van Nhien, T. Docsa, P. Gergely, M-D. Charavgi, P.V. Skourti, E.D. Chrysina, P. Tamás, L Somsák, Synthesis of variously coupled conjugates of D-glucose, 1,3,4-oxadiazole, and 1,2,3-triazole for inhibition of glycogen phosphorylase, Carbohydrate Research 346 (2011) 1427-1438.

31. D. Goyard, M. Baron, P.V. Skourti, A.S. Chajistamatiou, T. Docsa, P. Gergely, E.D. Chrysina, J-P. Praly, S. Vidal, Synthesis of 1,2,3-triazoles from xylosyl and 5thioxylosyl azides: evaluation of the xylose scaffold for the design of potential glycogen phosphorylase inhibitors, Carbohyd. Res. 364 (2012) 28-40.

32. E. Bokor, T. Docsa, P. Gergely, L. Somsák, C-Glucopyranosyl-1,2,4-triazoles As New Potent Inhibitors of Glycogen Phosphorylase, Med. Chem. Lett. 4 (2013) $612-615$.

33. W.A. Loughlin, S.S. Schweiker, I.D. Jenkins, L.C. Henderson, Synthesis and evaluation of C8-substituted 4.5-spiro lactams as Glycogen Phosphorylase a inhibitors, Tetrahedron 69 (2013) 1576-1582.

34. A.L. Kantsadi, S. Manta, A-M.G. Psarra, A. Dimopoulou, C. Kiritsis, V. Parmenopoulou, V.T. Skamnaki, P. Zoumpoulakis, S.E. Zographos, D.D. Leonidas, D. Komiotis, The binding of C5-alkynyl and alkylfurano[2,3-d]pyrimidine glucopyranonucleosides to glycogen phosphorylase b: Synthesis, biochemical and biological assessment, Eur. J. Med. Chem. 54 (2012) 740-749. 
35. B. Konya, T. Docsa, P. Gergely, L. Somsák, Synthesis of heterocyclic N-( $\beta-D-$ glucopyranosyl)carboxamides for inhibition of glycogen phosphorylase, Carbohyd. Res. 351(2012) 56-63.

36. C.A. Lipinski, Lead- and drug-like compounds: the rule-of-five revolution, Drug Discov. Today 1 (2004) 337-34.

37. A. Leach, M. Hann, J. Burrows, E. Griffen, Lead discovery and the concepts of complexity and lead-likeness in the evolution of drug candidates, Mol. Biosyst. 2 (2006) 429-446.

38. D. Fattori, Molecular recognition: the fragment approach in lead generation, Drug Discov. Today 9 (2004) 229-238.

39. S.S. Schweiker, W.A. Loughlin, C.L. Brown, G.K. Pierens Synthesis of new modified truncated peptides and inhibition of glycogen phosphorylase J. Pept. Sci. 15 (2009) $442-450$.

40. W.A. Loughlin, I.D. Jenkins, M.J. Petersson, Cyclodehydration of N-(Aminoalkyl) benzamides under Mild Conditions with a Hendrickson Reagent Analogue, J. Org. Chem. 78 (2013) 7356-7361.

41. M.J. Petersson, I.D. Jenkins, W.A. Loughlin, The use of phosphonium anhydrides for the synthesis of 2-oxazolines, 2-thiazolines and 2-dihydrooxazine under mild conditions, Org. Biomol. Chem. 7 (2009) 739-746.

42. M. Bodansky, Practice in Peptide Chemistry, Springer-Verlag, Weinheim, 1984.

43. C.A. Lipinski, F. Lombardo, B.W. Dominy, P.J. Feeney, Experimental and computational approaches to estimate solubility and permeability in drug discovery and development settings, Adv. Drug Deliv. Rev. 23 (1997) 3-25.

44. M. Congreve, R. Carr, C. Murray, H. Jhoti A 'rule of three' for fragment-based lead discovery?, Drug Discov. Today 8 (2003) 876-877.

45. I.V. Tetko, J. Gasteiger, R. Todeschini, M.A. Mauri, D. Livingstone, P. Ertl, V.A. Palyulin, E.V. Radchenko, N.S. Zefirov, A.S. Makarenko, V.Y. Tanchuk, V.V. Prokopenko, Virtual computational chemistry laboratory - design and description, J. Comput. Aid. Mol. Des. 19 (2005) 453-463.

46. I.V. Tetko, V.Y. Tanchuk, Application of associative neural networks for prediction of lipophilicity in ALOGPS 2.1 program, J. Chem. Inf. Comp. Sci. 42 (2002) 11361145. 
47. C.A. Lipinski, F. Lombardo, B.W. Dominy, P.J. Feeney, Experimental and computational approaches to estimate solubility and permeability in drug discovery and development settings, Adv. Drug Deliver. Rev. 46 (2001) 3-26.

48. S.J.Teague, A.M. Davis, P.D. Leeson, T. Oprea, The design of lead-like combinatorial libraries, Angew. Chem., Int. Ed. Engl. 38, (1999), 3743-3748.

49. W.L. Jorgensen, E.M. Duffy, Prediction of drug solubility from structure, Adv. Drug Delivery Rev. 54 (2002) 355-366.

50. Y.H. Zhoa, M.H. Abraham, J. Lee, A. Hersey, C.N. Luscombe, G. Beck, B. Sherborne, I. Cooper, Rate-Limited Steps of Human Oral Absorption and QSAR Studies, Pharm. Res. 19 (2002) 1446-1447.

51. Y.C. Martin, A Bioavailability Score, J. Med. Chem. 48 (2005) 3164-3170.

52. D.F. Veber, S.R. Johnson, H-Y. Cheng, B.R. Smith, K.W. Ward, K.D. Kopple, Molecular Properties That Influence the Oral Bioavailability of Drug Candidates, J. Med. Chem. 45 (2002) 2615-2623.

53. H.H.F. Refsgaard, B.F. Jensen, P.B. Brockhoff, S.B. Padkjaer, M. Guldbrandt, M.S. Christensen, In silico prediction of membrane permeability from calculated molecular parameters, J. Med. Chem. 48 (2005) 805-811.

54. I.R. Kelsall, S. Munro, I. Hallyburton, J.L. Treadway, P.T.W. Cohen, The hepatic PP1 glycogen-targeting subunit interaction with phosphorylase a can be blocked by Cterminal tyrosine deletion or an indole drug, FEBS Lett. 581 (2007) 4749-4753.

55. P.A. Lanzetta, L.J. Alvarez, P.S. Reinach, O.A. Candia, An improved assay for nanomole amounts of inorganic phosphate, Anal. Biochem. 100 (1979) 95-97.

56. H.H. Hess, J.E. Derr, Assay of inorganic and organic phosphorus in the 0.1-5 nanomole range Anal. Biochem. 63 (1975) 607-613.

57. A.L. Hopkins, G. M. Keserü, P. D. Leeson, D. C.Rees, C.H. Reynolds, The role of ligand efficiency metrics in drug discovery, Nature Rev. Drug Discov. 13 (2014) 105121.

58. S.A. Thomson, P. Banker, D.M. Bickett, J.A. Boucheron, H.L. Carter, D.C. Clancy, J.P. Cooper, S.H. Dickerson, D.M. Garrido, R.T. Nolte, A.J. Peat, L.R. Sheckler, S.M. Sparks, F.X. Tavares, L.Wang, T.Y. Wang, J.E. Weiel, Anthranilimide based glycogen phosphorylase inhibitors for the treatment of type 2 diabetes. Part 3: X-ray crystallographic characterization, core and urea optimization and in vivo efficacy, Bioorg. Med. Chem. Lett. 19 (2009) 1177-1182. 
59. J.M. Hayes, D.D. Leonidas, Computation as a Tool for Glycogen Phosphorylase Inhibitor Design, Mini-Rev. Med. Chem. 10 (2010) 1156-1174.

60. H.M. Berman, J. Westbrook, Z. Feng, G. Gilliland, T.N. Bhat, H. Weissig, I.N. Shindyalov, P.E. Bourne, The Protein Data Bank, Nucleic Acids Res. 28 (2000) 235242.

61. SYBYL-X (Version 2.0), Tripos International, St. Louis, MO, (USA), 2012 http://www.tripos.com

62. A.N. Jain, Surflex: fully automatic flexible molecular docking using a molecular similarity-based search engine. J. Med. Chem. 46 (2003), 499-511.

63. E. Kellenberger, J. Rodrigo, P Muller, D Rognan, Comparative Evaluation of Eight Docking Tools for Docking and Virtual Screening Accuracy Proteins: Struct. Funct. Bioinform. 57 (2004) 225-242.

64. C. Selvaraj, S.K. Tripathi, K. K. Reddy, S.K. Singh, Tool development for Prediction of pIC50 values from the IC50 values - A pIC50 value calculator. Curr. Trends Biotech. Pharm. 5 (2011) 1104-1109.

65. G. M. Keserü, G. M. Makara, The influence of lead discovery strategies on the properties of drug candidates. Nat. Rev. Drug Discovery, 8 (2009) 203-212.

66. C-S. Lee, J.S. Koh, K.D. Koo, G.T. Kim, K-H. Kim, S.Y. Hong, S. Kim, M-J. Kim, H.J. Yim, D. Lim, H.J. Kim, H.O. Han, S.C. Bu, O.H. Kwon, S.H. Kim, G-C. Hur, J.Y. Kim, Z-H. Yeom, D-J. Yeo, D-J. Dipeptidyl peptidase-IV inhibiting compounds, methods of preparing the same, and pharmaceutical compositions containing the same as an active agent, WO 2006104356, In PCT Int. Appl. 2006, p 197.

67. M.E. Sergeev, Convenient synthesis of $\alpha$-amino acid-derived cyclic amides for use as building blocks for protease inhibitors, Lett. Org. Chem. 3 (2006) 857-860.

68. L. Ribeiro, Aminocarbonyloxymethyl ester prodrugs of flufenamic acid and diclofenac: suppressing the rearrangement pathway in aqueous media, Arch. Pharm. 340 (2007) 32-40.

69. O. Sato, A. Tanbo, Optically active tropocoronands having amino acid residues in linker chains: syntheses, metal coordination properties, and their abilities as an asymmetric catalyst, Heterocycles 64 (2004) 357-366.

70. J.P. Devlin, W.D. Ollis, J.E. Thorpe, R.J. Wood, B.J. Broughton, P.J. Warren, K.R.H. Wooldridge, D.E. Wright, Antibiotic actinonin. III. Synthesis of structural analogs of actinonin by the anhydride-imide method, J. Chem. Soc. Perk. Trans. 19 (1975) 83041. 
71. J.A. Grzyb, M. Shen, C. Yoshina-Ishii, W. Chi, R.S. Brown, R.A. Batey, Carbamoylimidazolium and thiocarbamoylimidazolium salts: novel reagents for the synthesis of ureas, thioureas, carbamates, thiocarbamates and amides, Tetrahedron 61 (2005) 7153-7175.

72. T-Y. Guo, L-Y. Zhang, G-J. Hao, M-D. Song, B-H. Zhang, Preparation and properties of uniform-sized polymer beads imprinted with N-CBZ-L-phenylalanine, Int. J. Polym. Mater. 54 (2005) 743-755. 


\section{List of Captions}

\section{Figures}

Fig. 1. Structures of heterocyclic compounds 1-21 in fragment library.

Fig. 2. Morpholine scaffold mimetic of peptide backbone

Fig. 3. Structures of docking ligands $\mathbf{3 0}, \mathbf{3 1}$ and $\mathbf{3 2}$.

Fig. 4. Compound 9 docked into the AMP binding site of HLGP. Binding site key interactions (top, compound 9 in atom colours and residues in blue) and Molcad surface (bottom, coloured by lipophilic character: blue, polar; brown, nonpolar). Yellow lines indicate hydrogen bonding.

Fig 5. Compound 11 docked into the purine binding site of HLGP. Binding site key interactions (top, compound $\mathbf{1 1}$ in atom colours and residues in blue) and Molcad surface (bottom, coloured by lipophilic character: blue, polar; brown, nonpolar).

Fig. 6. Compound 7 docked into the purine site of HLGP. Binding site key interactions (top, compound 7 in atom colours and residues in blue) and Molcad surface (bottom, coloured by lipophilic character: blue, polar; brown, nonpolar). Yellow lines indicate hydrogen bonding.

Fig. 7. Compound 13 docked into the indole site of HLGP. Binding site interactions (top, Compound $\mathbf{1 3}$ in atom colours and residues in blue) and Molcad surface of the channel (bottom, coloured by lipophilic character: blue being polar and brown being nonpolar). Yellow lines indicate hydrogen bonding.

\section{Schemes}

Scheme 1: Synthesis of morpholines 15, 17 and 19 (a) $\mathrm{NaOH}$, benzyl chloroformate, rt, 30 min; (b) morpholine, EDC.HCl, HOBt, DIPEA, rt, 16 h; (c) $\mathrm{H}_{2}$, Pd-C, ethanol, acetic acid, rt $48 \mathrm{~h}$; (d) $\mathrm{H}_{2}$, Pd-C, ethyl acetate, rt, $48 \mathrm{~h}$.

Scheme 2: Synthesis of morpholine 21 (a) morpholine, EDC.HCl, HOBt, DIPEA, rt 16 h; (b) $\mathrm{H}_{2}, \mathrm{Pd}-\mathrm{C}$, ethyl acetate, rt 48 h; (c) $\mathrm{HCl} /$ Ether, rt $2 \mathrm{~h}$.

\section{Tables}




\section{Table 1}

Calculated Lipinski Parameters and GPa inhibition results for compounds 1-21.

Table 2

Calculated Ligand Efficiency (LE) and Ligand-Efficiency-dependent Lipophilicity (LELP) of compounds $1,5,7,9-13$ and 19

\section{Table 3}

Cscore values for compounds 5, 7, 9, 11-13 and 19 docked into AMP, purine and indole binding sites of HLGP 